\title{
Job Quality in Segmented Labor Markets: The Israeli Case*
}

\author{
Shoshana Neuman \\ Department of Economics, Bar-Ilan University, Israel; \\ CEPR, London; \\ and \\ IZA, Bonn
}

\begin{abstract}
:
Till the early-1990s the collectively-bargained labor contract (between the trade-union that presented the employees, and the employer or the employers'-association) was the norm, granting salaried workers a stable and protected labor contract. Thereafter, and more significantly after 1995, the share of unionized workers dropped constantly, to almost half of its peak level (of more than 80 percent). In parallel, two other types of contracts became more common: personal temporary contracts (between an individual worker and his employer), and contracts between a labor-contractor and employees who are employed in a triangular mode of employment (employee-contractor-client). The latter involves precarious employment and is more common among the more vulnerable sub-populations of new-immigrants, disabled individuals, Israeli-Arabs, foreign-workers and women. The contractual changes resulted in work instability, growth of the secondary labor market and segmentation. Efforts to protect the disadvantaged secondary labor-market workers include legislation, reforms, new regulations, and enforcement of all the above.
\end{abstract}

Keywords: Israel; labor market segmentation; labor contracts; collective bargaining; contracted labor; immigrants; foreign workers; regulation

JEL Classification: J15; J21; J31; J41; J51; J58; J61; J81

* The author is grateful to the ILO for research support, within the framework of a comparative project on "Labour Market Segmentation". I would also like to thank the participants of a workshop on "Labour Market Segmentation" (held at the ILO in Geneva, on December $11^{\text {th }}-12^{\text {th }}, 2012$ ), as well as ILO colleagues (in particular, Sandrine Cazes and Mariya Aleksynska), for very helpful comments on earlier versions of the paper. This study is also available as an ILO Working Paper No. 55, within the "Conditions of Work and Employment" WP series. 


\section{Job Quality in Segmented Labor Markets: The Israeli Case}

\section{Introduction}

The Israeli labor market has undergone profound transformations over the past several decades, with the emergence of new forms of contractual segmentation that have sharpened the fragmentation that already existed along ethnic, religious and gender lines. The increased fragmentation is due in large part to major transformations in the industrial relations system. Starting in the early 1990s, the Israeli industrial relations' system began a transition from a Continental corporatist system to an Anglo-American pluralist system. This change, combined with other global and domestic forces, resulted in significant changes in labor contractual arrangements, leading to an increase in segmentation.

Until the early-1990s, the collectively-bargained labor contract was the norm is Israel. Eightyfour percent of salaried workers in the Israeli labor market were unionized, with 95 percent of them belonging to the powerful General Histadrut trade-union. Contracts were negotiated, signed and instituted at the nation-wide, sectoral, and individual plant level, and extended to all salaried workers. But beginning in the early-1990s, and more significantly after 1995, the share of unionized workers has dropped consistently, falling to almost half of its peak. In parallel, two other types of contracts became more common: personal temporary contracts (between an individual worker and his or her employer), and contracts between a labor-contractor and employees who are employed in a triangular employment relationship (employee-contractorclient).Two distinct groups of workers are employed by temporary personal contracts: highlyqualified, professional workers (e.g., in the high-tech industry) who typically prefer this type of contract, which grants higher wages at the cost of less job protection, and at the other end, lowskilled workers who have little choice but to accept temporary contracts which entail both lower wages and much less job stability and job protection. Triangular contracted employment involves precarious employment and is more common among the more vulnerable sub-populations of new-immigrants, disabled individuals, Israeli-Arabs, foreign-workers, and women. The contractual changes have resulted in a growth in work instability, wage inequality, and poverty.

This report analyses the evolution of changes in the Israeli labor market over the past several decades, focusing on characteristics, industrial relations and types of labor contracts. It details the different segments of the Israeli labor market, focusing on its dual (primary-secondary) structure and the gradual changes in the composition of the secondary labor-market. It goes on, analyzing the role of institutions, legislation, policies and enforcement of labor-law and labor regulations, in monitoring these changes. In particular, efforts to protect the disadvantaged secondary labor market workers (immigrants, contracted-workers and foreign-workers) are discussed. The last section offers policy implications and remedies that could help upgrade the Israeli labor market. 


\section{Main characteristics of the Israeli labor market}

\section{A snapshot of the Israeli society, economy and labor market}

\section{Demographic stratification:}

The Israeli population is stratified on several levels: The first level is between Israeli Jews and Israeli Arabs. In 2011, the Israeli population of 7.8 million was composed of a majority of 75.4 percent Jews and a large minority of above 20 percent Israeli-Arabs (17.3 percent Moslems, 2.0 percent Christians, and 1.6 percent Druze); 3.7 percent claim to have no religion (Central Bureau of Statistics - CBS - Annual Statistical Abstract, 2012). The Jewish population is internally stratified along two lines: ethnicity and religiosity. The two major ethnicities are defined by country of origin: Easterners (Sepharadi Jews) who originate from Asian/African/Middle-eastern countries, and Westerners (Ashkenazi Jews) whose origins are in European/American countries. In the late-1980s, after the disintegration of the former USSR, about 1 million of Russian Jews have immigrated to the State of Israel (within 4-5 years). This major inflow of highly-educated immigrants enriched the multi-cultural Israeli society and added around 20 percent to the labor force. ${ }^{1}$

Another type of stratification, within the Jewish population, is defined by level of religiosity. The main division is between ultra-Orthodox Jews, referred to as Haredim (14 percent of the Jewish population in 2010; Ben-Moshe, 2012) ${ }^{2}$ and other Jewish individuals. Interestingly, Israel ranks first in a ranking of "Cultural Globalization” (Raab et al., 2008, Global Index, rankings for 2002). The ethnic and religious stratification probably granted her this first place.

The ethnic/religious sub-groups are highly segregated: Data from the CBS 2009 Social Survey on religiosity of spouses indicate that more than 60 percent marry within their religious group. The figures of religiously homogenous marriages are extremely high among the ultra-Orthodox (95 percent). There is rare intermarriage between Jews and Arabs. High residential segregation between the various groups and separate educational systems further exacerbate segregation, separation and stratification. Labor markets are also relatively segregated, in particular between Arabs and Jews.

Differential birth-rates within the various groups result in different age distributions and will lead to future changes in the relative shares: The groups of the ultra-Orthodox and of Moslem Arabs are expected to have significant relative growth. Projections for 2030, based on the reasonable assumption of some decrease in birth-rates within all ethnic/religious groups, yield estimates of 44 percent growth of the total Israeli population that is unevenly distributed between the sub-

\footnotetext{
${ }^{1}$ Israel provides a large, rich and varied pool of immigrants to observe. They come from a wide range of countries and have diverse educational and professional backgrounds. The most significant wave of immigration arrived in the country right after statehood, when between 1948 and 1952 mass immigration of 711 thousand supplements a population of 630 thousand. Immigration did not stop ever since and starting in 1989, brought in the last major wave from the former USSR (see Neuman 2005, and Table 1).

2 The definition and determination of ultra-Orthodox Jews (Haredim) is somewhat problematic, as CBS Labor Force Surveys do not classify individuals by their level of religiosity. Ultra-Orthodox Jews are usually defined using the question on "last institution of study". Male respondents, who report that yeshiva (an institution for the advanced study of Jewish religious texts) is their last place of study are labeled as ultra-Orthodox. A similar approach is used also for the classification of ultra-Orthodox women.

study of Jewish religious texts) is their last place of study, are labeled as ultra-Orthodox. A similar approached is used also for the classification of ultra-Orthodox women.
} 
populations. Major deviations from the overall population growth are expected among: the ultraOrthodox (growth of 134 percent), Moslem Arabs (growth of 65 percent) and secular Jews (down to 20 percent) (Ben-Moshe, 2012). ${ }^{3}$ These forecasted demographic changes have major implications for the Israeli society and in particular for the labor market: much lower labor-forceparticipation-rates, coupled with large families in the Arab and Haredi sector, are expected to lead to intensified poverty, diminished growth, rising welfare budgets and higher dependencyratios. $^{4}$

A more recent segment of the Israeli society is composed of low-skilled overseas migrantworkers, employed mainly in the sectors of construction, agriculture and care-giving. Starting in the early-1990s, they were first recruited to replace Palestinian work-commuters. The numbers, however, grew steadily and dramatically, reaching about 200 thousand since the late-1990s (222,000 in 2011). Lately, about 50,000 cross-border workers (some of them asylum-seekers) also joined this segment of foreign-workers. Obviously, there is a major spill-over from the stratified society to labor market segmentation, as will be suggested below.

\section{The Israeli economy and labor market:}

Israel enjoyed strong economic growth for most of the past two decades. Despite a slowdown in the early 2000s and the global financial crisis in 2008-09, economic output grew at an average annual rate of over 4 percent (as population grew as well, per-capita GDP grew by a lower annual average of over 3 percent). The recent economic crisis that affected (and still affects) most industrialized countries hit less hard the Israeli economy. In 2009, when GDP of OECD countries dropped by an average of 3.8 percent, Israel experienced a (minor) growth rate of 0.8 (the percapita average growth rate in OECD countries was -4.4 percent, compared with -0.9 percent in Israel). In 2011, per-capita GDP growth rate in Israel was 2.8 percent, versus 1.4 percent in OECD countries. The performance of the Israeli economy is even more pronounced when total GDP growth is considered: 4.7 percent in Israel, versus 1.9 in OECD countries (Table 1; Bank of Israel Annual Report, 2011). Economic growth is powered by the high-tech sector which also accounts for over 40 percent of exports and benefits from large investments in Research and Development (R\&D). The most recent available 2009 data indicate that it ranks first in terms of investment in civilian R\&D as percentage of GDP at 4.5 percent in Israel, versus a median of 2.1 percent in OECD countries (second ranks Finland with 4.0 percent and last comes Greece with 0.5 percent; Israeli Central Bureau of Statistics: "Main Science and Technology Indicators", 2011). The technologically oriented Israeli industry attracted foreign investment that established production plants and R\&D centers. However, the high-tech industry, which offers attractive working conditions, provides only 7 percent of jobs. At the other end many low-skilled disadvantaged workers (many of them women, Israeli Arabs, disabled individuals, immigrants and foreign-workers) are employed in poor jobs in the secondary labor market (mainly in the industries of construction, cleaning, security, agriculture and private services) (see sub-section on

\footnotetext{
${ }^{3}$ Under the assumption of stability of current fertility rates, the projections indicate higher growth rates of the ultraOrthodox and the Arab-Moslem groups (153 percent, and 72.7 percent, on the background of 49.5 percent growth of the total Israeli population) ( Ben-Moshe, 2012).

4 “Dependency-ratios" are defined as: The ratio of dependents (children aged 0-14, and retirement-age individuals women over 62 and men over 67), to the working age population (between 15 and retirement-age). In 2008, the dependency-ratio in Israel was 60.9, significantly higher than the OECD average of 48.2. The difference is driven mainly by differences in fertility rates: The average number of children in Israel is almost double compared to OECD countries (3.0 versus 1.7) (World Bank Statistics; Ben-David, 2010).
} 
triangular work contracts and Section 3). The divided economy, coupled with low labor-forceparticipation-rates among Haredi Jews and Arab women, lead to relatively high poverty rates (19.9 percent for the whole population, versus an average of 10.9 in OECD countries; around 50 percent for Arabs and close to 60 percent for Haredim: OECD, 2010) and to income inequality. The Gini Index of net income fluctuates around 0.33 to 0.39 and is higher than the OECD average that was 0.31 in 2010. The Gini Index of gross income (before taxes and subsidies) is also higher than the OECD average of 0.45 and moves around 0.5 (Table 1). Despite the relatively high levels of poverty and income inequality, Israel belongs (in 2011) to the group of countries with a "very high human development". Israel ranks $17^{\text {th }}$ in a list of 194 countries, with a Human Development Index (HDI) of 0.888 (ahead of the United Kingdom, France, Finland, Austria, Belgium and Italy; See United Nations, 2011).

Unemployment rates are relatively low: 5.6 percent in 2011, compared to an average of 8.0 percent in OECD countries, 9.9 percent in the Euro-zone and 9.0 percent in the United-States (Table 1; OECD Economic Outlook, 2011; IMF World Economic Outlook, 2011). Higher unemployment rates were evidenced at the early-1990s due to the massive Russian immigration, and the early-1990s slowdown. Unemployment was not affected by the global financial crisis of 2008-09. Interestingly, unemployment rates among immigrants, that were high shortly after immigration (early-1990s), slowed down significantly and since 2005 they are even lower than parallel figures for the total population (Table 1). Inflation rates are also relatively low: 2.2 percent in 2011, versus an average of 2.9 percent in OECD countries (Table 1).

Labor-force-participation-rates (LFPRs) display some minor increase between 1990 and 2011 (Table 2). They are still lower compared to the OECD average (a difference of about 10 percentage points: 57 and 67 percent, respectively, in 2011). Two groups are responsible for the low Israeli figure: Israeli-Arab women and Haredi men. LFPRs are extremely low among Arab women and in particular among Moslem-Arab women (in 2011: 22.7 percent among Arab women, 18.8 percent among Moslem-Arab women, versus 58.9 percent among Jewish women. See CBS Labor Force Survey, 2012. This disparity also accounts for most of the population gender difference). Only one out of four Haredi men is working. The remainder 75 percent is engaged full-time in religious study. About 50 percent of Haredi women are employed, however many of them work in part-time and low-pay jobs. A closer examination of LFPRs of workingage individuals (25-64) demonstrates that Israeli, Jewish, non-Haredi women are key contributors in the Israeli labor market. Data of the Ministry of Industry, Trade and Labor (2012a) indicate that in 2011 the LFPR of this sub-group was 80 percent, compared to a much lower figure of 66 percent of same-aged women in OECD countries. Overall, Israeli LFPR is negatively affected by the low rates among Israeli Arab women (29 percent within the 25-64 age-group) and Jewish Haredi women (66 percent), leading to an overall somewhat lower rate in Israel. Parallel figures for Jewish non-Haredi Israeli men are identical in Israel and in OECD countries: 86 percent (76 percent among male Israeli-Arabs and 48 percent among male Haredi Jews). Efforts of increasing LFPRs (and consequently also decreasing poverty rates) should therefore be targeted at the Haredi and the Arab population groups.

Interestingly, for most of the two-decade time period, LFPRs are higher among new-immigrants (possibly, because there are almost no Haredi individuals among the new immigrants). The high LFPRs of immigrants, coupled with the low unemployment rates, demonstrate their successful integration into the Israeli labor market. 


\section{Types of labor contracts}

Labor contracts in the Israeli labor market can be classified into three major groups:(1) collectively-bargained labor contracts, (2)personal/individual temporary employment contracts; and (3) triangular contractual arrangements with workers hired by independent contractors and suppliers of services, or workers supplied by temporary work-agencies. Each of the three types of contracts and labor arrangements will be discussed separately, on the background of the changing industrial relations system, which has driven the contractual changes. The possibility of having a contract that qualifies for more than one type will also be considered. ${ }^{5}$

\section{Collectively-bargained labor contracts:}

Collective bargaining in Israel is administrated by the Collective Agreement Law (1957). The Law includes broad rules regarding industrial relations, employees' rights, terms of employment, and prerogatives of the parties to the agreement. The law distinguishes between two types of collective agreements: 'general collective agreements' that cover the entire workforce (state/nation-level agreements) or an entire industry (industry-wide agreements), and 'special collective agreements' that relate only to one employer or one workplace (plant agreements). Collective agreements always involve a trade-union that represents the workers. Bargaining usually began at the national level (termed the 'framework agreement') ${ }^{6}$ and produced pay increases and other benefits for all union members, which were frequently extended by an 'extension order' (issued by the Minister of Labor) to encompass the entire workforce nationwide. Next, industry bargaining took place in main industries, resulting in collective agreements with additional benefits and provisions particular to that industry. These agreements too were often expanded to the entire industry. Subsequent to the national and industry agreements, many workplaces negotiate plant agreements, yielding benefits specific to those plants (Harpaz, 2006). Collective agreements apply to all the workers that are covered by the agreement and an individual contract between the employer and employee is redundant and non-existent.

The collectively-bargained contract was the standard labor contract till the early-1990s. By that time, 84 percent of salaried workers in the Israeli labor market were unionized. Coverage of labor collective agreements was almost complete, granting salaried workers a stable and secure collectively-bargained labor contract (Cohen et al., 2003).

The collectively-bargained labor agreements at the state-level were based on the corporatist principles of the tripartite cooperation: (i) the General Federation of Labor $^{7}$ (in Hebrew:

\footnotetext{
${ }^{5}$ A different distinction (with no overlap between categories), is offered by Cohen et al. (2003) and Haberfeld et al., (2006), who classify workers by union membership and by coverage of collective agreements (two indicators of union density, the former is voluntary and the latter is determined by legal arrangements and political circumstances). They distinguish between the two dimensions and relate to a 2x2 typology: Members and covered (insiders of the industrial-relations' system); non-members and not-covered (outsiders); covered but non-members (partials); and members but not-covered (residuals).

${ }^{6}$ The last 'framework agreement' was signed in 1995. There were attempts to sign a new 'framework agreement' in 2006, which did not materialize.

7 The term 'federation' is inaccurate. The Histadrut was one primary organization and not a federation of different trade-unions. It should also be noted that the Histadrut was founded in 1920, long before statehood in 1948. In fact,
} 
Histadrut, or General Histadrut) that unionized most workers in the Israeli labor force; (ii) the national employers' association; and (iii) the state.

(i) The Histadrut was the dominant player in the tripartite system. Its power rested on four pillars: (a) its political alliance with the Labor Party that was in power uninterruptedly since statehood in 1948 and until 1977; (b) its vast and exceptional (compared to other corporatist systems) economic activity that made the Histadrut the largest non-state employer in Israel and the owner of holdings and assets; (c) its control over the pensions' market; and (d) its almost monopolistic position in the provision of health-care ${ }^{8}$ (Cohen et al., 2007). Leaving the pensions' and health care systems in the hands of the trade-unions, relied and even extended the concept of the 'Ghent system', which delegates the provision of major social services to the trade-unions in order to encourage and increase membership (Haberfeld, 1995);

(ii) Most employers of the private sector were organized in over 15 employers' associations, in order to unify their voices in negotiations, lobbying and policy making. The employers' associations were coordinated by the Coordinating Bureau of the Economic Organizations (since the mid-1980s the abbreviation FIEO is used - Federation of Israeli Employers' Organizations);

(iii) The state was represented by the Minister of Finance who brought to the negotiation table the governmental standpoint and authority. The state participated in negotiations with the social partners and gave them considerable leeway for state-wide collective agreements.

The law accorded much weight to state-level collective bargaining by securing the partners' autonomy in bargaining, and using extension orders that extended the collective agreements to cover all workers and all employers in the Israeli labor market. Still, other levels of negotiation existed:

○ Industry-level collective agreements could be negotiated and would be signed by the General Histadrut and the relevant employers' association (e.g., the Building Contractors Association - in the case of collective contracts that apply to the construction sector; the Manufacturing Association - representing employers in the industry sector; the Chamber of Commerce - on behalf of employers in the trade branch; the Banks' Association - for the banking sector; the Farmers' Association - on behalf of the agriculture sector);

○ Plant-level agreements could also be negotiated and signed by the General Histadrut (or any other representative trade-union) and the local employer at the plant. In many plants/firms there are local workers' committees, but they do not have the legal right to sign a labor contract. The representative trade-union is the party to the contract, representing the demands of the workers that are articulated by the local workers' committee.

Up until the mid-1980s, the collective agreements (at all levels) set wage and work practices, working conditions, as well as procedural matters pertaining to industrial relations. An

the Histadrut had a dual role: (i) maintaining the industrial relations system; and (ii) building and maintaining a Jewish State. The second task was sometimes in tension with social solidarity, affecting the Israeli Arab workers.

${ }^{8}$ Only 5 per cent of salaried workers were organized in trade-unions that were not part of the Histadrut, mainly in the National Histadrut that is affiliated with the right-wing Likud Party. The General Histadrut was the owner of the General Health Care System, while the National Histadrut owned and ran the National Health Care System. 
employee's salary was set by the collective agreement and derived directly from the occupation and job-description (the 'employment scale/ladder'), education and seniority. There was basically no flexibility in determining the salary of a new employee or changing the salary of an existing one, and employees could not be rewarded for unmeasured characteristics, such as ability. Workers enjoyed highly protective work conditions: dismissals were very rare as they had to be approved by the trade-union that naturally rejects them (in most cases) ${ }^{9}$; any change in terms of employment was subject to and contingent upon the consent of the employee's trade-union; workers enjoyed contributions by the employer to pension schemes, training schemes, and other social fringe benefits (e.g. travel allowances, sick leave, annual vacation pay, sabbatical). It should be noted that typical collective labor contracts specified an expiration date, when they had to be renewed and revised. It is rare that a contract had no preset duration or includes a clause permitting reopening or extension of the contract. ${ }^{10}$ In most cases, the revision led to wage increases and additional benefits for the workers. All in all, this type of contract guaranteed a major degree of work stability and protection.

This corporatist system began to disintegrate in the mid-1980s. There was a gradual trend of decentralization that took place, and nation-wide/sector-level collective bargaining was replaced by independent wage policies at the occupational and workplace levels (Kristal, 2002; Sussman and Zakai, 1996, 2004; Kristal and Cohen, 2007).

The decline in the corporatist industrial relations system was caused by a combination of universal and domestic reasons. Many of them are also relevant for a parallel decline in corporatism in other countries (a comparative analysis is presented in Blanchflower and Freeman, 1992). To name a few: (a) the increasing heterogeneity of the labor force led to more diversified interests that could no longer be represented by one representative trade-union; (b) the growing share of highly qualified and powerful workers (in particular in the high-tech sectors) that did not need collective representation and preferred personal negotiation of their labor contracts; (c) a compositional change of the economic branches within the economy. In particular, the move from traditional industry (where collective agreements were the norm) to services and to more difficult-to-organize sectors (e.g., high-tech and start-up industries); (d) globalization led to a flow of foreign capital and foreign workers into the country, as well as the shift of local plants to neighboring countries where labor costs were lower, leading to much more complex industrial relations that could no more be covered by local extensive collective agreements.

\footnotetext{
${ }^{9}$ This is the case at workplaces where the collectively-bargained agreement is open-ended and grants tenure (usually after some work period, e.g., in the public administration sector and in powerful monopolistic industries such as the Electricity Company and the Port Authority), and also at workplaces that do not have the 'tenure institution' but have instead the 'seniority institution' - workers who are not defined as 'temporary workers' can not be dismissed, even if they do not have formal tenure.

${ }^{10}$ Nevertheless, the duration of collective labor contracts is more flexible than their rigid wording seems to indicate. In particular, it is common practice that the terms of the old contract are automatically extended during the oftenprotracted holdout period between the stated expiration date of the old contract and the beginning of the new one, leading to an uninterrupted coverage of the contract (Danziger and Neuman, 2005). In a study that analyzed 2,103 contracts in the Israeli labor market, signed between 1975 and 1995, with a fixed termination date, Danziger and Neuman (2005) found that 86 percent of new contracts were signed after the expiration date of the previous contract. The average delay was 213 days, which is 33 percent of the average stated contract duration. The length of delay was significantly affected by various macro-economic factors (e.g., unemployment, inflation, elections) that shape the interests of both the workers and employers involved.
} 
But perhaps most significant and specific to the Israeli economy was the important erosion in the Histadrut's political and economic power. The four pillars mentioned above were shattered, as: The Histadrut lost its political support with the cessation of the Labor Party's hegemonic rule after the right-wing Likud Party came to power in the 1977 elections; the Histadrut lost its economic power following a process of selling of assets and holdings that began in the 1980s; the Ghent system was abandoned in the mid-1990s, by means of privatizing the pensions' market and separating health-care provision from union membership. In 1994, the National Health Insurance Law was passed (in force since 1.1.1995), and granted all Israeli citizens health-care services, unconditional on membership in the Histadrut. By 1996, about a year and a half after the healthcare reform, the union membership rate dropped to about 49 percent, down from a peak of 84 percent (Cohen et al., 2007). Figures of membership in the Histadrut, provided by the Histadrut, show a dramatic decrease of more than 60 percent, between 1994 and 1998: a figure of about 1,640,000 in 1994 collapsed to about 620,000 in 1998 (interview with Zilony, Head of the Economic and Social Department at the General Histadrut: 22.10.2012) . ${ }^{11}$

Further decreases in union membership and in coverage rates are indicated by surveys conducted by the Ministry of Industry, Trade and Labor (in 2000, 2006; see Haberfeld et al., 2006, for survey description and details): in the year 2000, 46 percent of salaried workers were union members, and 56 percent were covered by collective agreements. A breakdown by economic sector yields the following figures: 81 percent of public administration workers, 80 percent of employees in the public industries of electricity and water, 81 percent of employees in the education sector, and 68.1 percent of health-care workers, were covered by collective agreements. In the private sector the "banking, insurance and finance" sector ranks first with a coverage rate of 61.8 percent $^{12}$, followed by manufacturing with 57.5 percent (Cohen et al., 2007, Table 1, page 260). In 2006, membership further dropped to 37 percent and the coverage rate did not change (Cohen et al., 2007). ${ }^{13}$

The overall decline in union membership, was complemented by a rise in membership in independent unions outside the General Histadrut: By 2000, nearly 20 percent of union members in Israel were affiliated with independent professional unions (the unions of junior and senior academic staff in the six research public universities; two teachers' unions; the medical doctors' union; and the small union of journalists), about 14-16 percent (up from 5 percent) were organized in the National Histadrut. Recently a new independent trade union was established: 'Power to the Worker' that includes about 7,000 members (Zilony, 2012).

\section{Personal/Individual temporary contracts:}

Personal contracts ${ }^{14}$ do not involve a trade union and are determined through direct employeremployee negotiations, a channel that is non-existent in uniform collectively-bargained labor contracts. Personal temporary contracts in the Israeli labor market involve two distinct groups of

\footnotetext{
${ }^{11}$ The most recent data indicate that at the 2012 elections for Head of the General Histadrut 504,000 union members were listed (and had the right to vote).

12 There are however major differences within sub-sectors of this economic branch: while almost all employees in the banking sub-sector are covered by collective agreements, there are no collective agreements within the insurance sub-sector.

${ }^{13}$ It should be noted, that the unionization rate in Israel is still relatively high. Visser (2006), utilizing data for 14 European countries in the early-2000s, arrived at an average of 24.2, ranging from 6 percent in Spain to 53.1 percent in Italy (Table 1, page 42).

${ }^{14}$ The terms 'personal contracts' and 'individual contracts' will be used interchangeably.
} 
workers: professional highly-qualified workers (e.g., in the high-tech industry) who prefer this type of contract that grants them higher wages at the cost of less job protection, and at the other end- low-skilled workers who are forced to have temporary personal contracts which in their case entail both lower wages and much less job stability and job protection. Workers with a personal contract are denied the protections of the collective contracts. In particular, a personal contract employee is not protected by tenure/seniority. His or her contract has a limited duration (usually one year), which is extended for an additional period when it expires - provided that the employer wishes to retain the worker' services. Such an employment structure permits the layingoff of an employee, leading also to more managerial flexibility. The Israeli contractual system is unique in the sense that temporary personal contracts are not associated necessarily with the weak groups of workers or with poor work conditions. Personal contracts in the Israeli labor market can be further classified into three sub-types (Sussman, 1995):

- Personal contracts at work places where the majority of workers have a collective labor contract and a small share of employees (highly-qualified and senior employees - or at the other end of the spectrum - temporary and low-qualified workers) have a personal contract. The wages of workers with a personal contract can be higher compared to wages of workers who are employed under a collectively-bargained contract (this will be the case for highly-qualified employees) or lower (in the case of low-qualified workers). A major example for this sub-type of personal contracts is provided by the sector of publicadministration that has the largest share of coverage by collective agreements, and at the same time also offers (beginning in the 1990s, based on the resolutions of the Sussman Committee, established in 1989) personal contracts mainly to senior and to more qualified professional/academic workers, in order to prevent them from moving to the higher-pay private sector. In this case, personal contracts grant higher wages at the cost of lower protection and less job stability. The share of workers with a personal contract within the public-administration sector has grown constantly: from about 1 percent in 1991 to 7 percent in 2009 (out of a total of about 60,000 workers in December 1990 and about 73,000 employees in December 2009; see Michelson, 2012). The growth-rate is more impressive when only academic workers are considered: from about 1 percent in 1997 to close to 20 percent in 2009. During the time-period of 1997-2009 about 2,500 employees switched from a collective contract to a personal one, more than 1,800 of them were academic workers (Michelson, 2012).

Opening up the public sector to the option of personal contracts provided a unique natural experiment that can shed light on a comparison of personal contracts vis-à-vis collective contracts, providing quantitative measures. Michelson (2012) employed personal data of a pool of almost one million observations, for the years 1997-2009, (180,577 annual observations relate to academic workers), in order to examine the effects of the new policy on workers' wages and promotion. Results of multiple regression income equations (controlling for a set of explanatory variables; see Michelson, 2012, Table 1, page 10) clearly indicate that they enjoy an income premium of 33 percent. It is even higher (by additional 11 percent) among female workers. However, women in the public administration sector have on average a wage disadvantage of 16 percent that is only partially cancelled out by their higher premium for switching to the new type of contract. Switchers also get higher returns for firm-tenure (about 0.6 percent per year). Another interesting finding is that employees who switched to a personal contract have a much higher propensity to quit the current work place compared to their companions who 
were offered a personal contract and preferred to stay with the old one. As Figure 1 indicates, starting in the second year, switchers were more likely to quit compared to their co-workers who rejected the offer of a personal contract. The disparities grow over time after 8 years the probability of quitting is 43.4 percent for 'switchers' and 32 percent for 'non-switchers'. The explanation for this finding could be related to the personality of the former who are most probably more ambitious and willing to take risks (as indicated by the move to the more risky personal contract). This finding also implies that one of the targets - to prevent the qualified employees from quitting the public sector - has not been achieved. Personal contracts to highly-qualified workers also become more common in government ministries (a sub-section of the public-administration sector): Annual administrative reports published by the Ministry of Finance demonstrate a clear stable upward trend in the share of workers who are employed by a personal contract: from 4.0 percent in 2004, to 5.7 percent in 2008, and to 10.7 percent (out of 57,905 workers) in 2011. Their wages are higher compared to the majority of workers who have a collectively-bargained contract (Ministry of Finance, annual Reports for 2006, 2009, 2012).

Figure 1: Public administration sector, 1997-2009: Probability (in percentage) of quitting the current workplace*

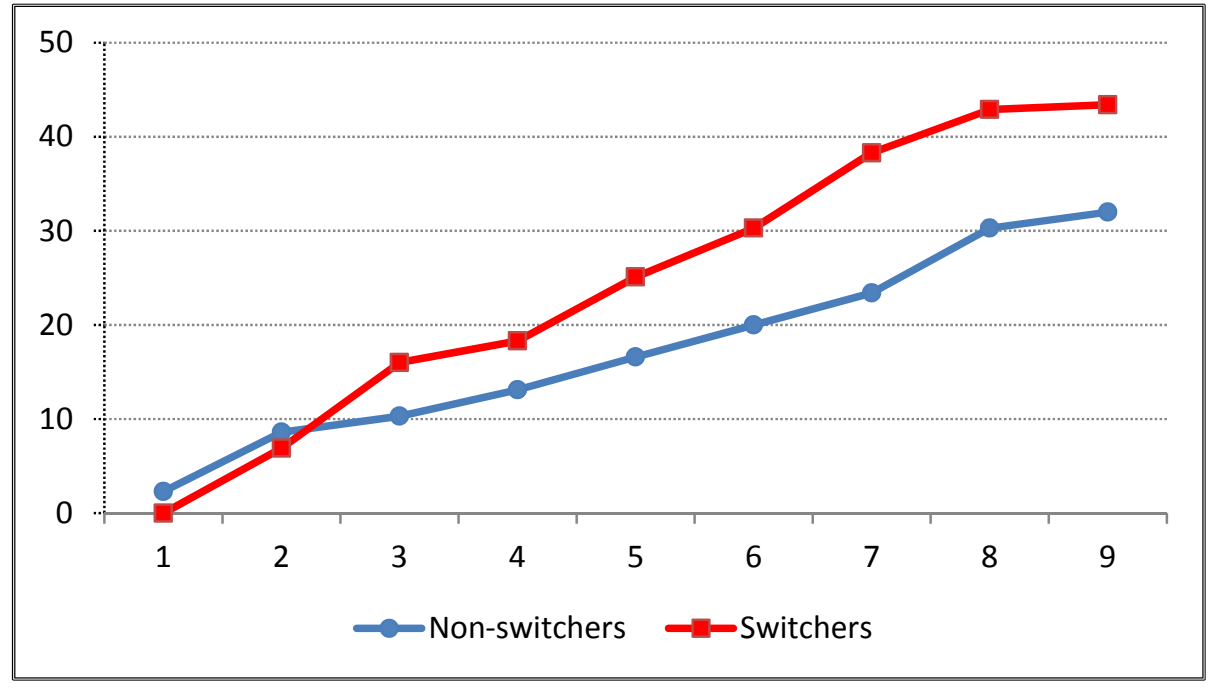

*Note: For 'switchers' to a personal labor contract and 'non-switchers' (who were offered a personal contract and preferred not to accept), by years since offer was accepted/made Source: Graphical representation of results from Michelson, 2012

At the other end of the occupational ladder, many low-qualified/non-professional workers also have personal temporary contracts. These workers are forced into this type of contract that, in their case, entails low wages and also low job protection and stability. In this group of workers are included low-skilled employees in the public and private sectors, low-skilled contracted-workers (see sub-section on triangular employment) and foreign workers (see section 3); 
- Work places where all workers are employed under personal temporary contracts, but the local workers' committee is a partner in wage negotiations and in the individual wage setting process;

- Work places where all workers have an individually negotiated labor contact and there is no local union of workers. This category includes workers employed in high-tech industries ('golden-collar workers') and various professionals, such as accountants, lawyers, insurance agents and other specialists. These workers seem to prefer a personal contract that guarantees high wages, at the cost of low job protection and low stability. The General Histadrut tried to recruit high-tech workers but all these attempts failed. Even at the burst of the "High-Tech Bubble" in the early 2000s, when masses of workers were unemployed, the Histadrut failed to attract them. Similarly, other professional workers, particularly at early stages of their careers, do not seek the succor of unions. They are willing to give up job security in return for higher pay (Harpaz, 2006).

Kristal and Cohen (2007) found that the increasing share of personal contracts has led to greater wage-inequality in the Israeli labor market. ${ }^{15}$

Unfortunately the CBS Labor Force Surveys do not include a question on the type of contract that the worker holds. Figures of the overall number/share of employees with an individual contract in the Israeli labor market are therefore not readily available (except for the public administration sector - presented above). Data drawn from surveys conducted by the Ministry of Industry, Trade and Labor in 2000 and 2006, suggest that: in 2000 about 34 percent of workers had an individual contract and the share increased to 41 percent in 2006 (Haberfeld et al., 2006). ${ }^{16}$

Historically, Israel relied heavily on collective bargaining to regulate labor markets, creating a well-established scheme of bargaining rules governing the collective sphere, but neglecting the individual arena. Scholars of law use the term 'procedural gap' when referring to the lack of an explicit set of rules of conduct that relates to the interactions between employers and employees with a personal contract. This 'procedural gap' leads to further instability and lower job security evidenced by workers with personal contracts. The labor courts ${ }^{17}$ harness 'good-faith' principles to establish process rights for non-unionized employees. ${ }^{18}$

\footnotetext{
${ }^{15}$ The effect of unions on income inequality has been debated for many years within the economics literature. Until the 1970s, and reflecting the plant-level industrial relations system in the US, the dominant view was that unions tended to increase wage inequality (Johnson, 1975). Freeman (1980) presented data that challenged this view. Recently the relationship between unions and inequality attracted renewed interest as researchers have struggled to explain increases in wage inequality in many countries. The fact that two of the countries with the largest declines in unionization - the United-States and the United-Kingdom - also experienced the biggest increases in wage inequality raised again the question whether these two phenomena are related. Card et al. (2004) present evidence of a positive relationship.

${ }^{16}$ They are classified as "non-members" (in trade unions), "not covered" (by collective agreements). See Haberfeld et al. (2006), Table 4, page 11.

${ }^{17}$ In 1969, the Labor Court was established, in which a professional judge sits together with the workers' and employers' representatives (Mundlak, 2009).

${ }^{18}$ However, it is claimed that "although the labor courts readily emphasize the corresponding duties of both employers and employees to act in good faith, judicial decisions, in determining liability, rarely are based solely on the breach of good faith dealings" (Rabin-Margalioth, 2011, page 883).
} 


\section{Triangular work contracts:}

One of the major byproducts of the transformation of industrial relations in the Israeli labor market from corporatism to pluralism, combined with other global and internal forces, was the rapid growth of triangular modes of employment ${ }^{19}$, which led to further segmentation and polarization of the labor market and also to growing inequality. There are four types of employment that can be grouped under the triangular model ${ }^{20}$ :

- Outsourcing of functions, such as: computer services, advertising, call centers, accounting and legal services. The contractor produces the service/good on his own premises, using his own facilities and employees, and provides the user/client with the final service or good. The workers are formally and practically employees of the contractor. They usually enjoy the benefits of other workers of the firm (e.g., the law firm or accountancy firm) and therefore this type of agency does not lead to precarious employment and will not be discussed here (for more on outsourcing of functions in the Israeli labor market, see Galin, 1999);

- Manpower agencies (sometimes also referred to as: Temporary Help Services - THS, or Temporary Employment Agencies - TEA): This was the classic employment agency that (as is evident form its title) delivers inherently temporary work, usually replacement of absentees (e.g., replacement of clerical work; replacement of employees is on holiday; on maternity-leave; or on sick-leave). The worker remains an employee of the agency, which is responsible for his/her wage and all other fringe benefits and obligations accorded by labor law. The work is performed however on the premises of a third party, namely the user (or client). There is some benefit to the worker in being employed by the contractor and not by the user, potentially acquiring the advantages of continuous employment and stability;

- Labor-contractors: the contractor provides the user with workers as long as the user is interested in their services. The work is performed on the premises of the user where the worker is subject to his instructions and specifications, and the employment might continue with the same user for long periods of time. When the user/client does not need or want the contracted-workers anymore, the contractor is supposed to assign them to a different workplace. Contracted-work is often used for 'pay-rolling' purposes and in order to bypass collective agreement obligations, by claiming that the workers are employees of another entity (the agency or the contractor), even though the real contact of the employee is with the user (Raday, 1999);

\footnotetext{
${ }^{19}$ Different terms have been used for this concept: market-mediated arrangements; flexible working practices; vulnerable work; contingent work; precarious employment; disposable work; peripheral work; nonstandard employment. See Kalleberg (2000) for a comprehensive review of literature, and Vosko (2006) on the history of precarious employment. For a recent review of the development of precarious employment in Israel, see Harpaz (2012) and Davidi (2012).Interestingly, in 1997, in Convention 181 (“Convention Concerning Private Employment Agencies”), the ILO reversed its previous stance that opposed private labor market intermediaries (the 1949 Convention 96: “Convention Concerning Fee-Charging Employment Agencies”). The ILO 1997 convention legitimized triangular relationships (not only for job placement but also for direct supply of labor services). It was done to allow managerial flexibility and close the gap between principles and practice (Vosko, 1997).

${ }^{20}$ There is another type of contracting: foreign-worker agencies that have been established in the construction industry only. This is a byproduct of a recent regulation (came into force on 1.5.2005) that requires foreign-workers in the construction sector to be employed by a registered construction-contractor, only via a licensed employment agency, and not directly by an on-site construction-contractor (Wallach, 2008). This special case that only applies to foreign-workers in the construction industry will not be included in our discussion.
} 
○ Labor sub-contractors: This relatively new mode of labor-contracting was formed in order to bypass licensing regulations and other legal restrictions imposed on labor-contractors (Nadiv, 2005). Makover (2012) claims that the bulk of contracted-workers are supplied by sub-contractors. Fensirrer (2011) presents evidence that in recent years about 80 percent of contracted-workers are employed by sub-contractors (see Figure 2).

We will refer to the latter three types interchangeably as contracted-work. They are all using a 'legal construct' to undermine workers' rights. Practically, it is a pervasive strategy for hiring individuals where no regular positions are available, to avoid the need to grant them tenure in the public sector (where tenure is granted almost automatically after a relatively short period of employment), or to bypass a formal user/worker employment relationship. In fact, it has created one of the most disadvantaged groups in the Israeli labor market, often experiencing adverse working conditions (Harpaz, 2006). The contracted-workers belong to a disadvantaged class of employees, not only in job security and wages (in many cases below minimum wage), but also in regards to promotion, training opportunities, seniority rights, social inclusion and more. The discrimination may often be double-discrimination, since labor-contracting is likely to be concentrated in the already disadvantaged sectors in the labor market: ethnic minorities, immigrants, very young workers, unskilled workers, and women (Raday, 1999). Often the result is a frustrating and depressing work environment for the contracted-workers, which also affects their motivation and loyalty to the work place, and produces alienation and apathy. Moreover, jobs with high employment instability also cause health problems, in particular high psychological morbidity. A review study by Virtanen et al. (2005), that appraised 27 studies on the relationship between employment volatility and health, presents clear evidence on health risks of unstable employment.

The declared purpose of contracted-labor was the introduction of more managerial flexibility, but the main outcome was the deprivation of workers of employment benefits (Raday, 1999; Mundlak, 2004). ${ }^{21}$ This widespread mode of employment has resulted in entire sectors, such as cleaning and security, being dominated by contracted-labor workers. Providing services requires little capital investment, leading to fierce competition and as a result cutting wages of employees. While work in these service sectors could be physically demanding, only little knowledge or expertise is required leading to a large pool of potential workers, that agree to accept the unfavorable pay and work conditions (Davidov, 2005). Quite surprisingly, the Israeli public sector is a major employer of contracted-labor. The process started with the 1985 "Stabilization Program" 22 aiming to cut public employment costs. In the 1990s the process accelerated, with an increasing number of activities being contracted-out. It started with peripheral jobs such as: cleaning, secretarial work and security; and continued with core jobs, such as: teachers (in some special tracks), social-workers, school nurses and engineers. These 'new workers' perform the

\footnotetext{
21 The triangular employment mode has been criticized by many scholars. Some, like Ben-Israel, have for years called for complete abolition of this form of employment that leads to what Rifkin (1995) termed "the end of work", and a return to the classic employee-employer relationship with "the authentic contract". She presents compelling arguments to support her case, from social/moral/ethical/legal doctrines (see for instance, Ben-Israel, 1999).

${ }^{22}$ The main purpose was to stop the hyper-inflation that soared to annual levels of above 100 percent (146 percent in 1983, 444.9 percent in 1984, and 185.2 percent in 1985; Israel CBS, Annual Statistical Abstracts). The "Stabilization Program” included a broad package of steps, applied to all parties in the Israeli labor market: workers, employers and the government. The "Emergency Orders" that have been enacted included a major budget cut, in particular, an immediate significant dismissal of 4,000 public administration employees.
} 
same work at low wages without social benefits and without the job security (in particular tenure) that all public sector workers once enjoyed.

Figures and information of contracted-work are not readily available. To the best of our knowledge, no official figures are available, neither from the Ministry of Industry, Trade and Labor ('moital'), nor from the Israeli Central Bureau of Statistics (CBS). The CBS Quarterly Labor Force Surveys do not include a direct question on mode of employment. This is to some extent a problem of definition and classification, and also a political matter. There are instead various estimates:

- Data from a Histadrut survey, carried out in 1998, indicate that in the late-1990s, 4.2 percent of salaried workers in the business sector and 3.2 percent of employees in the labor force as a whole, were employed by contracted-labor companies. Those workers were considerably younger and included a larger share of women, compared to the general employed population (average age of 30 vs. 38.5; and female shares of 51.5 percent vs. 45.8 percent) (Achdut, Sola and Eizenbach, 1998);

- Estimates of labor-contracted employees, provided by the CBS for 2009, relate to about 150,000 employees, composing 5.4 percent of the total of 2.78 million workers. The majority of them are employed in the sectors of cleaning, security and personal caregiving services, earning an average monthly income of 4,182 shekel (half of the Israeli average monthly income at that time - above 8,000). The disadvantaged groups of immigrants and women are disproportionately represented within the sector of contractedworkers: about 50 percent of them are immigrants who arrived in the country following the 1990 wave of immigration from the former USSR (significantly above the share of immigrants in the population - 12.2 percent); more than a third of Ethiopian immigrants are contracted-workers; women, who compose less than half of the labor force, make-up for 65 percent of contracted-workers (Fenssirer, 2011);

- In recent years the CBS published figures of contracted-workers, based on Labor Force Surveys. However, these figures exclude workers employed by the growing number of sub-contractors (estimated to provide about 80 percent of all contracted-labor). For 2011, CBS reported 23.4 thousand workers who were employed by Temporary Work Agencies and contracting-firms (excluding sub-contracting modes of employments). More than a quarter (25.6 percent) of them belong to the age group of 18-24 (compared with a figure of 10.6 percent for the entire salaried work force) and one-third are immigrants who arrived in the country after 1990 (CBS, Labor Force Survey, 2012);

- Many unlicensed firms use creative complex legal constructs of sub-contracting (also termed as 'supply of services') to bypass licensing restrictions (Nadiv, 2005). As is indicated by Figure 2, between 2005 and 2009, the total number of contracted-workers remained relatively constant at around 150,000. The share of workers who are employed by sub-contractors that was already high in 2005 (71 percent) further rose to 78.7 percent in 2009; 
Figure 2: Workers employed by work-contractors, and by sub-contractors (thousands), 2005-2009

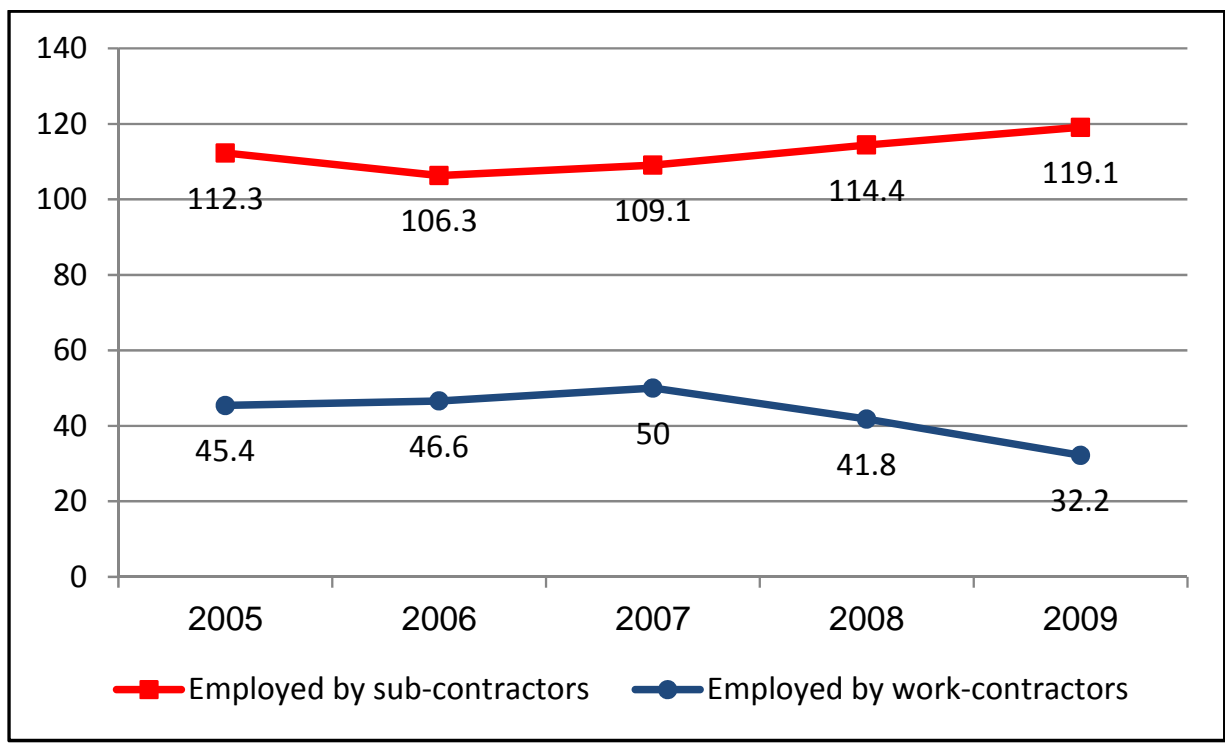

Source: Fenssirer, 2011, page 6

- Estimates that relate to contracted-workers in the public sector range between 15 to 20 percent of the total public sector labor force (Fenssirer, 2011). Contracted-labor in the public sector includes a large share of disadvantaged workers: women, Israeli-Arabs and immigrants (Galnoor et al., 1999; Galnoor, 2007; Paz-Fuchs, 2010). These workers do not have tenure like the majority of public sector workers who are employed by a collectively-bargained contract. The last published report of the Ministry of Finance (2012), on wages in the public sector, states that in 2011 contracted-workers in the public sector had a monthly income of 5,718 shekel for a full-time position - 36 percent less than the Israeli average monthly income of 8,900 shekel. Moreover, actual monthly earnings were much lower due to (involuntary) part-time employment of almost all public-sector contracted-workers: More than half (59.2 percent) had a 25 percent position or less; 23.3 percent worked at a 25-50 percent position; 15.2 has a position of 51-99 percent; and only a mere of 2.2 percent enjoyed a full-time position (Ministry of Finance, 2012);

- The Association for Civil Rights in Israel, states that in 2011 as much as 20 percent of employees are employed by labor-contractors or sub-contractors, about half of them in the public sector (figures to be found at www.acri.org.il). It should be noted that even the more modest estimates are well above respective rates in European countries and in the US, which are lower than 2.5 percent for temporary agency employment (Zilony, 2001; Verzberger, 2002; Fenssirer, 2011);

○ The use of outsourcing and contracted-labor-services by firms is widespread and intensive: a Survey on "Fair Employment and Enforcement of Labor Law" that was conducted by the Ministry of Industry, Trade and Labor ('moital') during May/June 2012 
covering 370 firms and 1,100 workers, indicates that in addition to the popular use of cleaning, security and private services (e.g., catering at the employer's site), a large share of firms are also outsourcing the more professional and high-pay services of accountancy (87.6 percent are contracting-out accountancy services), computing (38.1 percent) and legal consulting 24.0 percent). Moreover, more than half of firms are using more than one service. As Figure 3 below shows, a mere of 5.0 percent do not use triangular employment at all, more than 40 percent use one type of service, about a quarter use two triangular services, and more than a quarter of firms use three or more;

\section{Figure 3: Share of firms, by number of outsourced and contracted-services used, 2012}

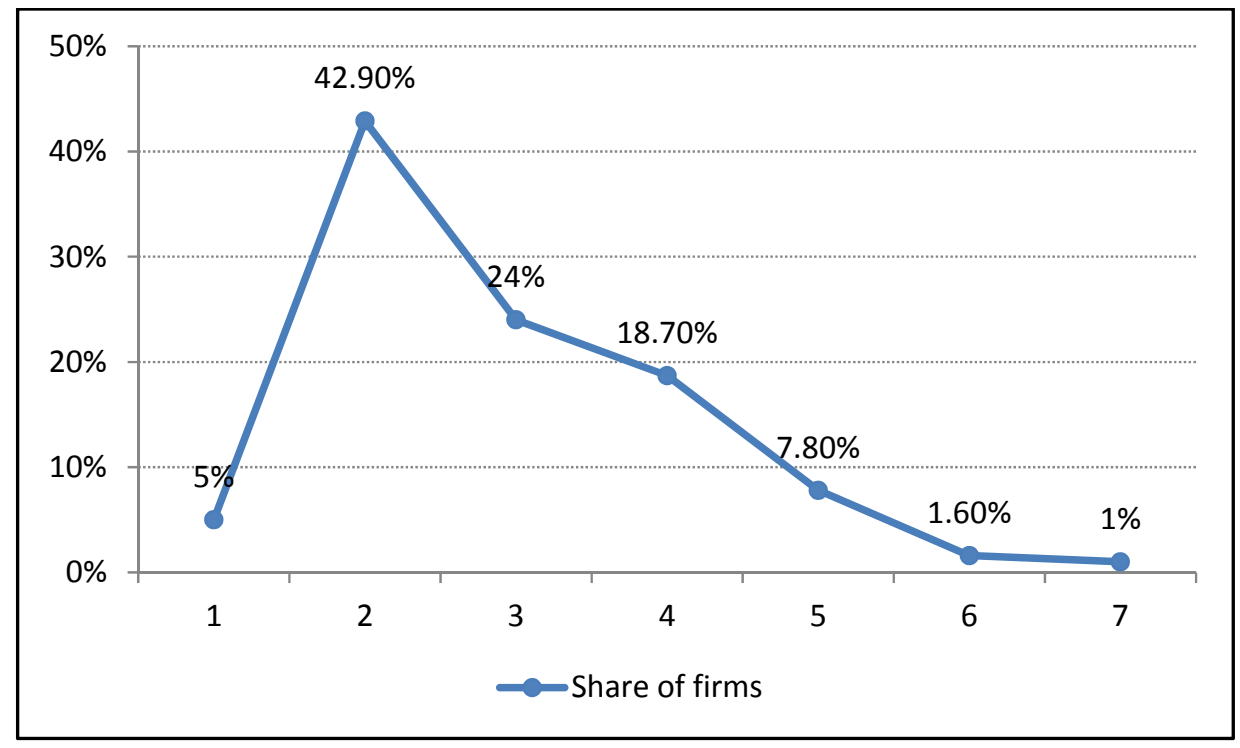

Source: Ministry of Industry, Trade and Labor ('moital'), special Survey on "Fair Employment and Enforcement of Labor Law", 2012b

Note: The question on the use of triangular employment does not distinguish between outsourcing of functions (the contractor produces the service/good on his own premises, using his own facilities and employees and providing the user/client with the final service or good - relates mainly to accounting, computing and legal services) and contracted-labor (the work is performed on the premises of the user where the worker is subject to his instructions and specifications)

- The number of labor-contracting licensed firms grew significantly in the 1990s, reaching (in 1998) a peak of 380 contracting-firms. The number decreased there-after, so that in 2002 only 280 firms were registered. The number further dropped to 233 in $2008 .{ }^{23}$ The sector of labor-contractors seems to be highly concentrated: in the early 2000s about 20 percent of the contracting-firms employed/provided more than 70 percent of contractedemployees (Nadiv, 2005).

\footnotetext{
${ }^{23}$ 'Moital' is responsible for the registration and licensing of contracting firms (a responsibility given by the 1996 Law of "Employment by Labor-Contractors", that requires the contracting firms to register and get a license). The Ministry therefore keeps records of the registered/licensed firms. The drop in the number of registered firms was most probably the result of the tightened registration requirements.
} 
The intensified and rapid growth of contracted-work over the last three decades established a new form of separation between two types of long-term workers in the same workplace: in-house employees versus labor-contracted employees. The long-term contracted-workers work in most establishments side by side with in-house employees of the user, performing the same job, without tenure and with inferior wages and work conditions.

In the past, most contracted-workers had personal labor contracts with the contracting firm. It was complex for trade-unions to organize these temporary contracted-workers, as they are often poorly educated, unaware of their rights, mobile between workplaces, widely spread geographically, and perhaps too frightened to seek organization. However, since collective bargaining with labor-contractors was permitted by the 1996 Law ("Employment of LaborContracted Employee"), there is an intensified trend of switching under the umbrella of collective agreements. In some cases industry-level agreements were signed (e.g., in the security and cleaning sectors, for workers employed in the public sector), and in many cases the agreements are local - between the contractor and the representative trade-union. In 2002, about two-thirds of registered contractors had collective agreements with their employees. Interestingly the more common representative trade-union is the National Histadrut, which was the partner in 41 percent of the agreements, versus 25 percent where the General Histadrut represented the contractedworkers (Nadiv, 2005). ${ }^{24}$ These collective agreements led to the establishment of separate bargaining units in the very same workplace, as well as two systems of wages and work conditions. They represent an improvement in the labor conditions of the contracted-workers, although they are still inferior compared with those of the in-house employees.

A glimpse of the poor status of contracted-workers is provided by the 'moital' survey on "Fair Employment and Enforcement of Labor Law" (2012b). An analysis of questions that relate to violations of workers' rights reveals that violations are much more common among contractedworkers than among in-house employees (in the same workplace). Five items were considered: (i) the employer refuses to pay for overtime, or pays less than official rates; (ii) the employer refuses to pay for annual vacation, or pays less than the regular rate; (iii) the worker does not have an official labor contract; (iv) salaries are paid late - on the $10^{\text {th }}$ of the month and afterwards; and (v) during the last year, the worker did not get the approved/correct monthly salary, at least once. As Figure 3 indicates, in all cases, violations of workers' rights are more widespread in the case of contracted-workers: three out of the five reported violations have a frequency of more than 50 percent. Significantly higher than the respective probabilities among in-house employees; the probability of denial of overtime payments is more than 3 times larger among contracted-workers (54.5 percent, compared to 16.4 percent in the case of in-house employees); the most severe violation (item 5) is much more common among contractedemployees (13.3 percent and 5.5 percent, respectively).

\footnotetext{
${ }^{24}$ In some cases workers organized at their workplaces and demanded their rights. Such groups of employees (e.g., security personnel at the Kaplan Hospital; cleaning personnel the Faculty of Agriculture in Rehovot, and at the Hebrew University; waiters at the restaurant 'Coffee to Go'; faculty of the Open University; kindergarten assistants in nurseries operated by 'moital'; workers at 'Cinema City'; cleaning personnel at the Ben-Gurion University - see Amos and Baharav, 2012), received legal and organizational support from "Clinics for Law and Welfare” that were established at university law faculties and were staffed by volunteering lawyers. In summer 2006 the clinic at TelAviv University initiated the "Workers' Organization" project that later led to the establishment of a new tradeunion: "Power to the Workers - A Democratic Trade Union", that was approved by the Court as a representative trade-union (Swirski, 2009).
} 
How satisfied are workers with the type of contract they have? Data on satisfaction scores by type of contract are not available. However, the 2000 and 2006 surveys of 'moital' included a question on satisfaction with the type of union membership/coverage. It appears that in 2000 more than 50 percent of sampled individuals were not satisfied with their coverage status: about 30 percent preferred more coverage of collective agreements, while about 25 percent opted for less coverage. Results were similar in 2006 too (Haberfeld et al., 2006).

\section{Job stability: movements between employment and non-employment}

As discussed above, the shares of workers with personal and with triangular contracts has grown considerably. Obviously, due to the absence of reliable time-series data of workers with each type of contract, transition matrices between types of contracts can not be constructed. However, general information on movements between employment and non-employment can shed light on job stability (in terms of work continuity) of Israeli workers. Our hypothesis is that the major transition from long-term collectively-bargained contracts to temporary personal and triangular labor contracts, led to a change in work patterns: a comparison of work histories in the 1980s and early 1990s versus the 2000s, is expected to show less job stability and more frequent movements between employment and non-employment.

Work histories of employees during two time periods, 1983-1995 and 2005-2010, were constructed using administrative data sets from the National Insurance Institute (NII) database. The NII receives information on individuals' employment start and finish dates for each period of continuous work. A work break was defined as non-work for at least one month. On the basis of this information, the timing and length of all periods of work and work breaks ${ }^{25}$ was computed. For each individual in the sample (who was working at the end of the time period) a vector of the timing and length of work periods and work breaks was recorded. Neuman and Ziderman (2003) used NII administrative data, spanning the period of 1983-1995, for a sample of 215,133 working-age (35-59 in 1995, and therefore at least 22 years old in 1983) individuals (104,240 men and 110,893 women, of these 69.8 percent of men and 62.9 percent of women were working in December 1995). The NII kindly responded to our request to construct a similar dataset for the recent six years spanning the period of 2005-2010, and to replicate the construction of corresponding work histories for the 72 months between January 2005 and December 2010. The data covered 1.7 million workers who were employed in December 2010: 52 percent of them were men and 48 percent were women. ${ }^{26}$ The use of administrative data, generated on a monthby-month basis, and supplied by employers, is more reliable than work history data in previous

\footnotetext{
${ }^{25}$ We do not know if the during the 'work break' the individual was unemployed or out-of-the-labor-force. However, as we refer to individuals who are in-and-out of the labor market, it is more plausible that during the 'work-break' they were unemployed.

${ }^{26}$ The data set for 2005-2010 covers all Israeli workers who were employed at the end of 2010. The Neuman and Ziderman (2003) study refers to a sample of workers who were also included in the 1995 Population Census, in order to be able to link work histories to data on personal characteristics drawn from the 1995 Census. The CBS undertook, for the authors, the complicated task of linking two large micro data sets - individual work information from the NII records, with socio-economic data from the 1995 Census.
} 
studies (e.g., Corcoran, 1979; Stewart and Greenhalgh, 1984) that were collected by surveys and were based on the memory of the respondents (a potential source of error).

Table 4 presents work histories (broken down by gender), presented by successive spells of employment (in-spells) and non-employment (out-sells), experienced by men and women during the 146 month period ending in December 1995, and during the 72 month ending in December 2010.

Although the analysis does not control for different economic and labor market conditions across two periods, it suggests that employment is less stable in 2005-2010 compared to 1983-1995. The most recent in-spell (following an out-spell), is much longer (in month) in 1983-1995. Some other indications: referring to the four-spell case we see that while in the first time period an average in-spell between two out-spells lasted close to 30 month (29.2 and 26.3, for men and women respectively), its duration dropped to almost half (16.5 months for the two genders) during the second time period. Similarly, relating to the five-spell case, the duration of an in-spell between two out-spells dropped from over 30 months (33.6 for men and 32.1 for women) to less about half (14.7 months for men and 16.9 for women). Other figures are in the same line. As the last line in Table 4 indicates, the share of workers who experienced many work interruptions (six spells or more) dropped marginally for men (from 23.6 percent to 15.1 percent) and significantly for women (40.3 percent to 19.1 percent). However, as the duration of the second more recent time period is less than half of the duration of the distant time period (72 and 146 months respectively), it means that over time there is an increase in the share of men who switched between work statuses six or more time and no change in the share of women.

The average duration of out-spells decreased as well, most probably due to improved job search strategies. The figures in Table 4 also indicate the narrowing of gender differences in work histories.

Our hypothesis, stating that the increasing shares of personal and triangular contracts led to less job stability, is therefore supported by the comparative data on work histories of Israeli salaried workers.

A more direct piece of evidence indicating the job instability of contracted-workers is provided by the CBS Labor Force Survey (2012). An examination of work continuity of contractedworkers (excluding workers employed by sub-contractors) during the last year (2011) reveals that only 62 percent worked 10-12 months. 16 percent were employed only 1-3 month, and equal shares of 11 percent were employed 4-6 months and 7-9 months, respectively (CBS, Labor Force Survey, 2012).

\section{Segmentation/duality in the Israeli labor market: a growing secondary labor market and a compositional change}

Labor market segmentation is frequently analyzed within the context of duality of the labor market. ${ }^{27}$ Quality of jobs is very different in the primary and secondary labor-market segments.

\footnotetext{
${ }^{27}$ Economists who examine duality of the labor market tend to use the terms of: primary and secondary labor markets, a term that will be used in this article too. Other scholars use the terms: internal versus external labor markets, or 'insiders' vs. 'outsiders' (e.g. Raday, 1999). Also, we analyze segmentation/duality of employees within
} 
Jobs in the secondary labor market are unstable and provide low wages, almost no training, no promotion prospects, and no returns on human capital investments (e.g., schooling; experience; firm tenure). Moreover, workers in the secondary disadvantaged sector are trapped in this segment, with a minimal mobility to the primary sectors that offers stable jobs with training and promotion possibilities. Following the early work by Piore $(1969,1971)$, advocates of the hypothesis that labor markets are characterized by a dual structure have posed a direct and continuing challenge to the neoclassical model of labor markets and, in particular, its human capital investment prescription for dealing with problems of poverty and low-pay (e.g., Cain 1976, who reviews the literature on dual labor markets from a neoclassical vantage point; McNabb and Psacharopoulos, 1981).

Segmentation of the Israeli labor market will be analyzed within the context of the dual labor market theory presented briefly above. There is some relationship between the type of contract that the employee has and the segment of labor market. For instance, contracted-workers have a much higher probability to be part of the secondary labor market. As we noted above, they have work conditions that resemble those of secondary labor market workers: low wages (half of the average); and low prospects of promotion, training and seniority rights. However, there is no oneto-one correspondence between type of labor contract and segment of the labor market. The most notable example relates to personal temporary contracts: workers with a personal contract could belong to the primary sector (in the case of highly-qualified workers in public-administration that switched to a personal contract, or workers in the highly-competitive high-tech industry) or to the secondary sector (e.g., in the case of low-qualified cleaning workers with a personal contract). Segmentation of the labor market is more closely related to the occupation/industry and/or to the socio-demographic group of workers (new immigrants, disabled workers, Israeli-Arabs, Haredi individuals) than to the type of contract, and will be analyzed within this context.

\section{Duality and the compositional change within the secondary labor market:}

Neuman and Ziderman (1986; 1992) presented evidence that the dual labor market hypothesis was relevant for Israel in the early-1970s: Dividing the sample of Jewish male workers into two groups (the Arab sample was too small for reliable statistical analysis), corresponding to primary and secondary sectors ${ }^{28}$, they found an average difference in monthly income of over 30 percent. $^{29}$ Employing regression analysis to examine differences in the wage determination process in the two labor market sectors, they presented evidence that, while human capital variables enhanced male earnings in the designated primary labor market, they failed to do so in

the labor market. It is also possible to focus on segmentation/duality of employers. Scholars (e.g., Maman, 1999) claim that the Israeli economy has a dual structure in which big business groups coexist with small firms.

${ }^{28}$ Data were drawn from the 1974 Israel Labor Mobility Survey. Categorization into primary and secondary labor market segments was done on the basis of occupational prestige ratings for Israel (Tyree, 1981). Although income does enter as one of the ingredients in measuring the relative prestige of occupations, the correlation between earnings and prestige scores in our sample was not found to be particularly high (0.47), so that the demarcation of sectors is not based on the same variables (usually income) that the analysis is attempting to explain. For more detail, see Neuman and Ziderman (1986). There is continuing debate in the literature over the demarcation of sectors. See for instance: Hodson and Kaufman $(1981,1982)$ who also criticize Tolbert, Horan and Beck (1980).

${ }^{29}$ The Labor Mobility Survey does not include data on fringe benefits received by employees that could add (in the 1970s) up to 30 percent to the monthly income (in particular, employers' allocation to the two main fringe benefits pension and training). The provision of voluntary fringe benefits in Israel is primarily dictated by collective agreements, which do not cover most workers in the secondary sector. It follows that the real income differential is much larger than 30 percent. See also Kristal et al. (2011) for more recent data and analysis. 
the secondary sector. In particular, schooling had a significant positive effect only in the primary sector (an average rate of return of 6.4 percent to each additional year of schooling in the primary sector, versus no effect in the secondary). Experience and tenure/seniority at the current place of work also had positive significant effects only in the primary sector. Neuman and Ziderman (1992) present evidence that the wife's education (number of years of schooling) augments husband's earning in the primary sector, but not in the low-status secondary occupations. The data also show that the two sectors are stratified along ethnicity lines, with significantly more workers of a Sepharadi origin in the secondary sector: 55.5 and 37.5 percent of workers, respectively. Workers in the secondary sector are also older, less educated, have less firm-tenure, and include a larger share of immigrants.

The duality of the Israeli labor market was further accelerated by intensified polarization between highly-skilled workers, who work mainly in high-tech industries, versus low-skilled workers who are lacking computing/internet/technical skills and are employed in the traditional blue-collar occupations (e.g., private services, construction, agriculture, low-tech industry). Ramos and Ballell (2009) use the term "the digital barrier" to emphasize the low mobility between these two sectors, and present evidence for the effect of this "digital barrier" on duality within the European labor market. A similar process was evidenced in the Israeli labor market. This process, coupled with the drastic change in the Israeli industrial relations' system, and external and internal/political changes, led to a compositional change and an increase in the size of the secondary labor market. Sepharadi Jews, and also Israeli-Arabs, were replaced by four new groups of disadvantaged workers:

i. Palestinian day-workers from the territories of the West Bank and the Gaza Strip (starting late-1970s). After the 1967 Six-Day War, when Israel occupied the West Bank and the Gaza Strip, Palestinians were allowed to work in Israel as day-workers. They found jobs mainly in agriculture, construction and services. By the mid-1980s and beginning-1990s, around 110 thousand were employed in Israel (see Table 5), although only less than half of them had permits. They constituted 6-7 percent of the total number of employed Israelis. The percentages are even more impressive in sectoral terms: at the peak, Palestinians held 25 percent of jobs in agriculture and 45 percent of construction jobs (replacing Israeli-Arab and Jewish-Sepharadi workers). One-third of West Bank labor force and about half that of Gaza were working in Israel. It should be added that nonPalestinian overseas migrant-workers were rare in the Israeli labor market at that time (Table 5). The deterioration of the political and security situation led to a decrease in the number of Palestinian commuters, down to 30.3 thousand in 2002. This significant decrease brought about a severe labor shortage in the construction and agriculture sectors, which since the late-1960s relied heavily on Palestinian workers. As Table 5 indicates the Palestinian workers were replaced by overseas foreign-workers. Consequently, the share of Palestinian workers (out of the total of non-Israeli workers) dropped dramatically from 97.7 percent in 1990 to around 15-20 percent in recent years;

ii. New immigrants from the former USSR (starting late-1980s). In September 1989, after the disintegration of the former Soviet Union, Russian Jews began immigrating to Israel in large numbers. The peak was in 1990 when in one year almost 200,000 Russian immigrants arrived in the country. In eight years, about one million immigrants joined the State of Israel, adding about 20 percent to the population (see Table 1). They naturally exacerbated the demand for housing, leading to increased demand for construction 
workers. Replacing the Palestinian workers by Russian immigrants seemed like a good solution that would instantly solve the problem of the shortage of construction workers and at the same time would provide jobs to the new-comers. ${ }^{30}$ However, the Russian immigrants did not fit into the construction (and agriculture) secondary labor market. Forty percent of them were highly educated professionals (compared to about 10 percent of native Israelis), not construction workers and citron pickers (Flug, Kasir and Ofer, 1992). Those who accepted construction (and other low-pay) jobs did so temporarily, till they could find a job in the primary sector that would fit their qualifications and experience. However, the older and less-qualified Russian immigrants (in particular women) were not able to move up to the primary sector. Russian immigrants still compose more than 50 percent of the secondary sector and many of them work as contracted-workers (Fenssirer, 2011). Data drawn from a recent CBS Social Survey indicate that about 85 percent of female new-immigrants are employed by a triangular employment system (compared to about 5 percent of native-Israeli women);

iii. Overseas foreign-workers (mainly since the early-1990s) and cross-border immigrants (late-2000s). When Palestinian workers became unavailable for employers, employers and employers' associations pressured the government to increase substantially the number of permits for non-Palestinian foreign-workers, in particular in the sectors of construction and agriculture that relied heavily on Palestinian workers. Large-scale recruitment of foreign (non-Palestinian) workers $^{31}$ took place, out-numbering the highest level of Palestinian commuters ever in the Israeli labor force. As Table 5 indicates, the number of non-Palestinian foreign-workers rose from 29.6 thousand in 1993 to a peak of 254.5 thousand in 2002, and their share (as percentage of the total non-Israeli workers) rose from 26.1 percent in 1993 to over 80 percent in the early 2000s (89.4 percent in 2002). About three-fourth of the non-Palestinian foreign-workers originate from Asian countries (Thailand; The Philippines; India; China; Nepal) and the remaining one-fourth comes from European countries (Former USSR; Poland; Bulgaria; Romania). The figure of nonPalestinian migrant-workers (Table 5) includes also cross-border workers. This is a more recent phenomenon that started in the late-2000s with an inflow of cross-border individuals who came mainly from Sudan, Eritrea, South-Sudan and Ivory Coast, crossing illegally the Israeli border with Egypt. Some of them are asylum-seekers who are under a life-threat if they return to their country of origin. By the end of 2006 there were a mere of 1,070 cross-border individuals and thereafter the figures rose dramatically, up to an annual inflow of about 15,000 in each of the following two years (14,735 in 2010 and 14,955 in 2011), totaling (by the end of 2011) 49,290 people (Nathan, 2011). ${ }^{32}$ With about

\footnotetext{
${ }^{30}$ The Ministry of Housing also adopted a plan to pay an income supplement (equal to employment benefits) to Israeli workers who accept construction jobs.

${ }^{31}$ We use the terms foreign-workers, migrant-workers, and non-Israeli workers interchangeably. They are subdivided into Palestinian- and non-Palestinian foreign-workers. Non-Palestinian foreign-workers include also crossborder individuals. Foreign-workers include legal and illegal workers.

${ }^{32}$ More detailed recent data (for December 2011, distinguishing between legal- and illegal foreign-workers) discloses the following figures: 88,864 entered the country as legal workers (out of which 15.9 percent - 14,127 individuals -
} 
10 percent of the work-force composed of foreign (non-Israeli) workers, Israel ranks at the high end of the industrialized economies that are heavily dependent on foreign labor. Foreign-workers are now a significant portion of the secondary labor market. They are willing to accept low-status jobs (that Israeli workers reject) because they do not consider themselves as part of the local status hierarchy - they are motivated mainly by wages, which are higher than what they could earn in their country of origin (Bartram, 1998). The import of low-skilled foreign-workers is believed to have downward pressure on wages and crowd out low-skilled Israeli workers, in particular Israeli Arab workers, whose labor costs are higher (Gottlieb, 2002). A report submitted in 2008 by an inter-ministerial committee, appointed for the reformulation of migrant-workers' policy, has a major concern that the constant increase in the number of foreign-workers in agriculture and in the care-giving sector will end-up replacing Israeli workers and depressing their wages (Eckstein, 2008). Ben-David (2010) also demonstrates a clear positive relationship between the share of non-Israeli workers and the rate of non-employment of Israeli Arab workers (Figure 28, page 264).

iv. Haredi workers. In recent years, growing numbers of Haredi women and men have joined the labor market. Due to low labor-market skills (see Tables 7 and 8), the majority of them are employed in the secondary labor market. One of the major targets of the new Israeli government that was established in March 2013 is to further increase labor force participation and integration of Haredi individuals.

Data limitations do not allow a precise replication of our 1986 study, in particular, a comparison of rates of return on human capital characteristics within the two segments of the labor market. However, the relevance of the "Dual Labor Market Hypothesis" for the Israeli labor market, will be examined using two sets of evidence: (i) a comparison of wages and of human capital traits of workers in the primary and secondary labor market segments in recent years; and (ii) a comparison of employment conditions and work satisfaction of employees who belong to more vulnerable groups of workers that are over-represented in the secondary segment of the labor market, in particular: Israeli-Arabs, Haredi workers, disabled workers, and new immigrants. Their personal traits, work conditions and work satisfaction will be compared to those of Israeli native workers.

\section{Wages and human capital characteristics of workers in the primary-and secondary labor} markets:

Data from the CBS Social Surveys for 2005-2011 were used for the calculation of monthly wages and human capital characteristics of Israeli workers employed in the primary and secondary labor markets. Non-Israeli workers (Palestinian and non-Palestinian foreign-workers) are not sampled in the Social Surveys and are therefore not included in the comparison presented in Table 6. Inclusion of foreign-workers, who belong to the most vulnerable group of workers, would have

are staying in the country after their work-permit has expired); 95,000 individuals entered the country on a tourist visa and over-stayed their visa; about 45,000 individuals crossed the border illegally - among them asylum-seekers; about 31,000 Palestinians with a work-permit; and a similar number of irregular Palestinian workers, from Jordan, the West Bank, and the Gaza Strip (Ministry of the Interior, data for 7/12/2011). The main sectors of employment of migrant-workers are still: agriculture, construction, geriatric-care and personal services. 
led to larger differences. The worker's occupation was used for assignment to the primary- and secondary sectors of the labor market. ${ }^{33}$

As is evident from Table 6, full-time wages of workers in the secondary labor market are 55.8 percent of comparable wages of workers who belong to the primary labor market. This very significant wage differential is partly explained by differences in education (a difference of more than three years of schooling) and in work tenure (a two-year difference). Secondary sector workers are also somewhat younger and therefore accumulated less general work experience. Data on type of labor contract is not provided by the Social Survey and classification of workers in the two sectors by type of contract is therefore not possible.

\section{Employment characteristics, personal attributes and satisfaction of disadvantaged groups of} workers:

Descriptive statistics for four groups of disadvantaged groups of workers, that are highly represented in the secondary labor market (Israeli-Arabs, Haredi workers, disabled workers, and new immigrants) vis-à-vis Jewish-veteran individuals are presented in Tables 7 (men) and 8 (women). The data relate to 2002 (in parentheses) and to 2008. The raw data are drawn from the 2002 and 2008 Social Surveys (descriptive statistics, based on these data are presented in 'moital' 2010b). The main findings are:

a. Haredi men and women have very low LFPRs: in 2008, 56.5 percent of Haredi men and 41.8 percent of women were not in the labor force, compared with respective figures of 19.5 and 24.9 for the reference group of Jewish veterans (percent of 'not in the labor' force equals 100 minus the LFPR and demonstrates the preference not be active in the labor market). There is some decrease in this voluntary exclusion from the labor force between 2002 and 2008, but the rates are still very high. The low LFPRs are correlated with the low levels of academic education and computer/internet use;

b. Israeli-Arab women experience even lower LFPRs: 71.4 percent in 2008 (down from 77.1 percent in 2002) are not part of the labor force. Educational attainments within this group are much lower compared to Jewish women (10.0 percent and 30.2 percent, respectively, have an academic education, in 2008) and even deteriorated between 2002 and 2008 (in 200216.7 percent of Israeli-Arab women had an academic education);

Figure 4 displays percentages of individuals who are not part of the labor force within the five groups, in 2008 and 2002, for men and women separately. As noted above, the most striking figures relate to Israeli-Arab women, who are almost absent from the labor market, and to Haredi men. There is however some improvement between 2002 and 2008, that gives hope for more integration of these two groups of workers into the labor market.

\footnotetext{
${ }^{33}$ Academic professionals, associate professionals including technicians, and managers were assigned to the primary labor market. Clerical workers (that are populated mainly by women and have low promotion prospects), sales and service workers, skilled blue-collar workers, and unskilled workers were assigned to the secondary sector. About 40 percent belong to the primary sector. Assignment by occupation is common in the literature that relates to duality in the labor market. Neuman and Ziderman (1986) used a more careful classification, based on occupational status scores (Tyree, 1981). However such scores are not available for recent years.
} 
Figure 4: Percentages of individuals who are not in the labor force, 2008 and 2002

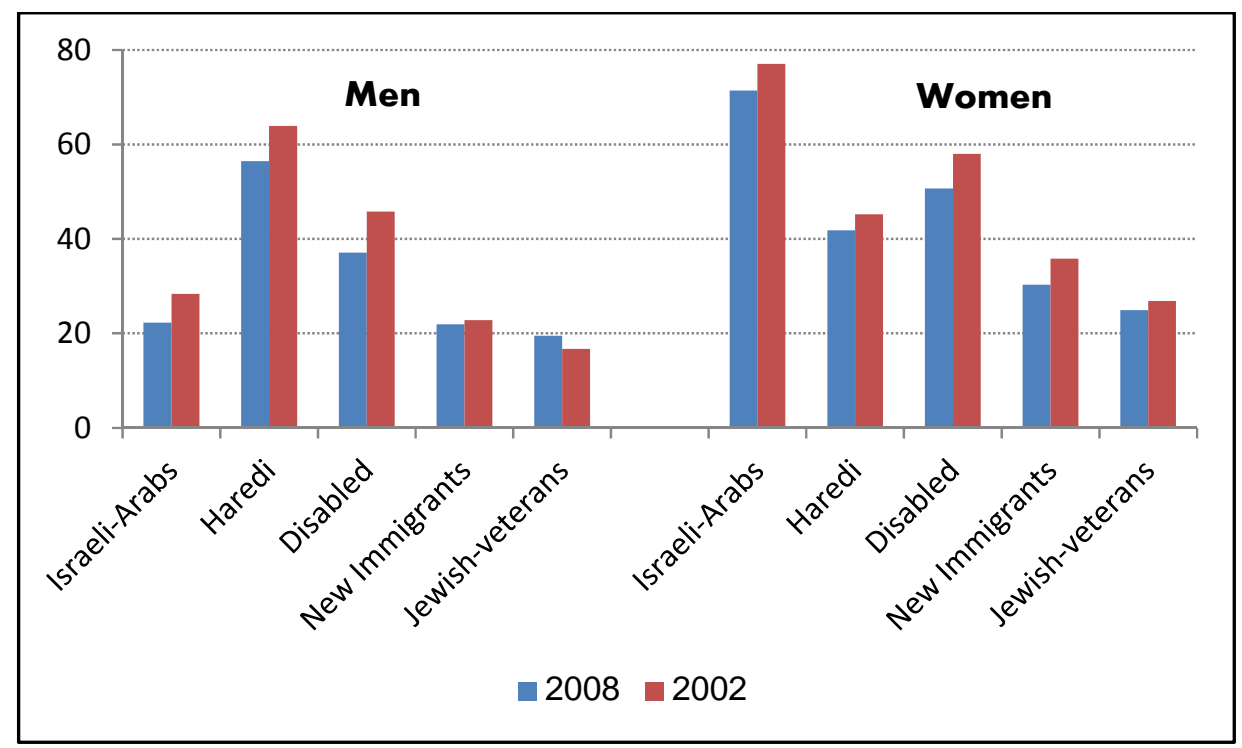

Sources: Tables 7 and 8

Figure 5 displays the percentages of individuals who have an academic education within the five groups, in 2008 and 2002, for men and women separately. The high educational attainments of new immigrants are evident, along with the much lower educational attainments of Israeli-Arabs, Haredi individuals and disabled workers. Differences between the genders are minor.

Figure 5: Percentages of individuals who have an academic education, 2008 and 2002

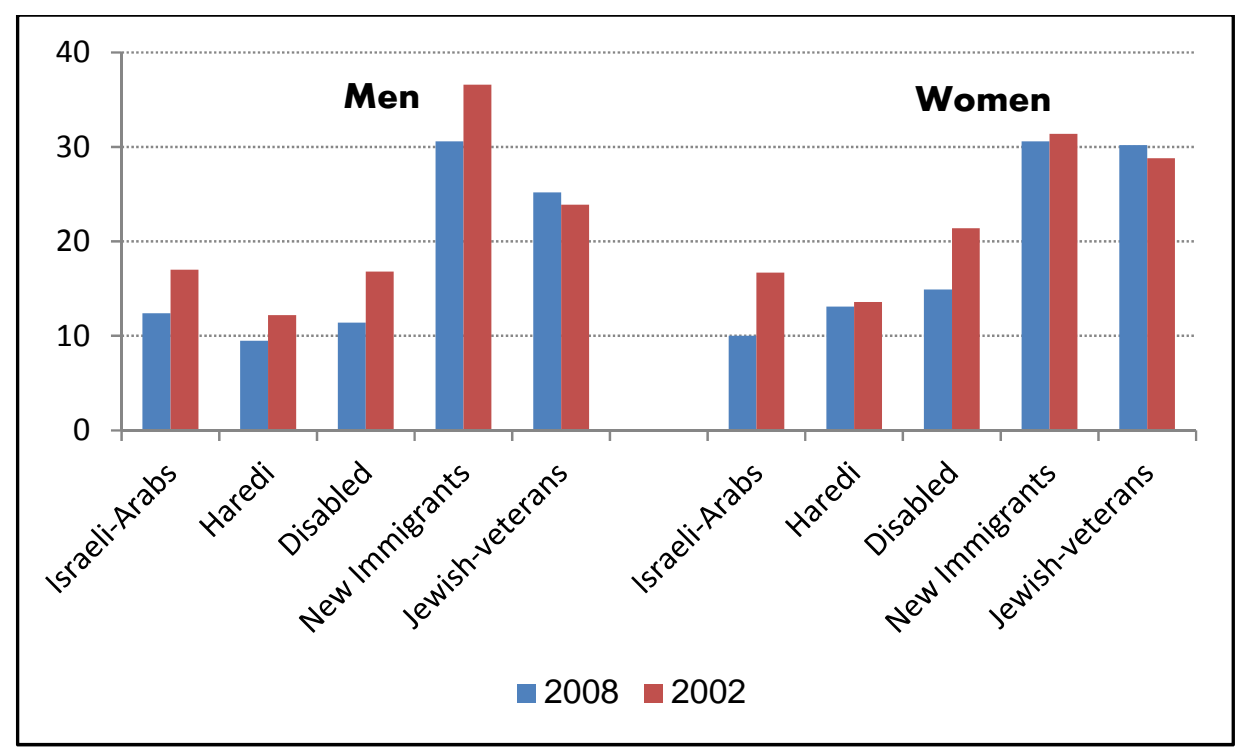

Sources: Tables 7 and 8 
c. Workers of the four deprived groups are disadvantaged in all aspects of the labor market: earnings, unemployment and representation on non-professional occupations: While about one-third of veteran Jewish male workers earn more than 10,000 shekel per month (around 50 percent more than the average monthly income) ${ }^{34}$, the figures drop to about half and less for the 4 groups of disadvantaged male workers. A comparison of 2002 and 2008 indicates deterioration in terms of income. The differences in income can be partly explained by the type of occupation: higher shares are employed in non-professional occupations. Unemployment rates are also higher within the weaker groups of workers, indicating less job stability;

Figure 6 displays the percentages of working individuals who earn a monthly income of above 10,000 shekel, within the five groups, in 2008 and 2002, for men and women separately. The inferiority of women's situation is evident: negligible shares of women who belong to the four weak sub-populations benefit from high income. Even within the reference group of native Jewish women, the shares are much lower compared to native Jewish men. The subordination of women in terms of income can not be explained by differences in education. As Figure 5 indicates, similar shares of women and men have an academic education. There is however some increase (between 2002 and 2008) in the share of women with high incomes, against a decrease in the share of men. The shares of workers with high incomes decreased (between 2008 and 2002) also within the groups of male disadvantaged workers, with the exception of new immigrants. These records could indicate deterioration in the economic status of secondary labor market workers, and on the other hand, successful absorption of male immigrants in the local labor market.

Figure 6: percentages of working individuals who earn a monthly income of above 10,000 shekel, 2008 and 2002

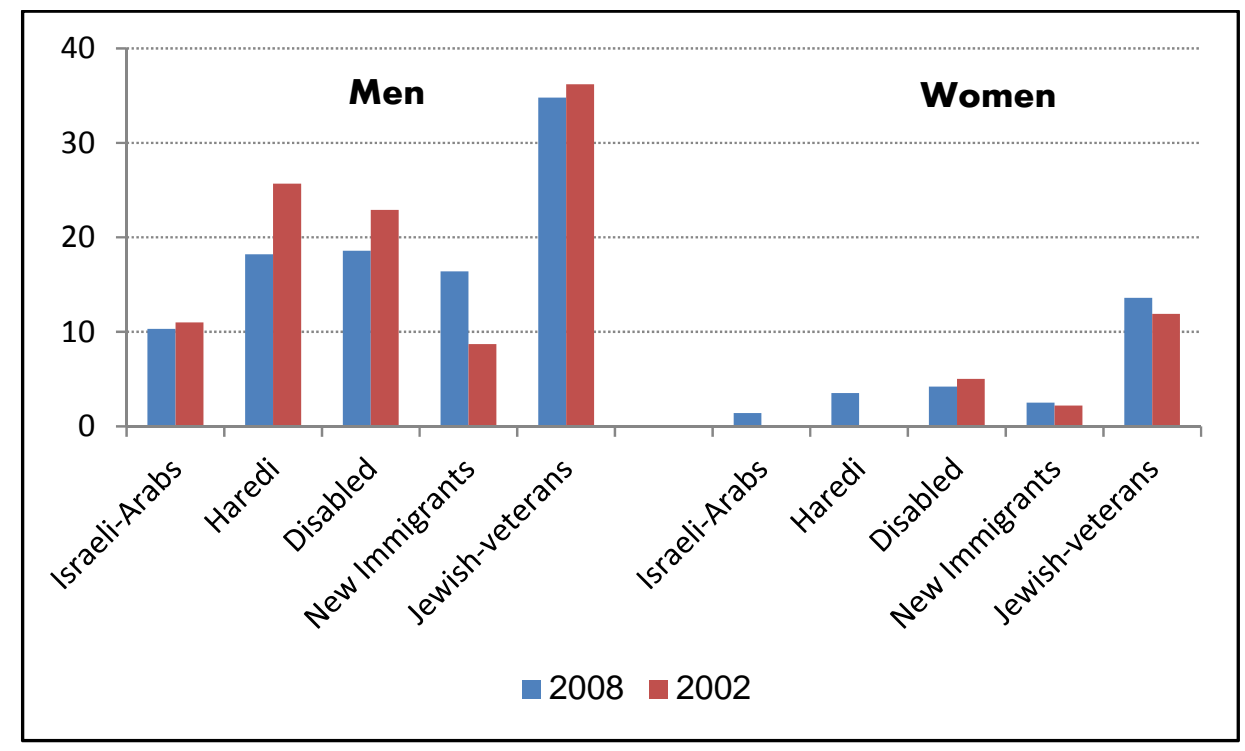

Sources: Tables 7 and 8

\footnotetext{
${ }^{34}$ In the 2002 survey the question related to a monthly income of 9,000 shekel. The two levels are similar in real terms and both are about 150 percent of the average income.
} 
d. Major differences between the genders are evidenced: disparities between the four inferior groups and the group of Jewish veterans are much more pronounced for women. For instance, focusing on income: the differences between veteran women and women who belong to the 4 weaker groups are much more striking than in the case of men. Moreover, also the privileged group of veteran Israeli women earns much less than veteran men: only 13.6 percent of veteran women compared with 34.8 percent of veteran men earn more than 10,000 shekel per month. Overall, a comparison of Tables 7 and 8,coupled with an examination of Figure 6, establishes the very low status of women in the secondary labor market and shows that women are exposed to double segmentation: along lines of gender and of type of labor market;

e. New-immigrants adjust fast to the Israeli labor market: this is indicated by a comparison of figures for 2002 and 2008. The share of men with a monthly income of 10,000 shekel doubles, and unemployment among male immigrants is even lower than among male veterans. The successful absorption is due, at least partly, to the very high educational attainments of the new immigrants - higher than those of Israeli natives;

f. Questions on satisfaction from labor income, the economic status (in general) and the health status were also included in the 2002/2008 Social Surveys. Tables 7 and 8 present the shares of individuals who are "very satisfied" and "not satisfied at all" with these three factors. With the exclusion of the Haredi group, members of the 3 other weaker groups report lower levels of high satisfaction and higher levels of absence of satisfaction compared to native Jewish Israelis - the differences are more evident for men than for women. Interestingly, deprivation in the labor market affects also the self-assessed health status: more veterans report "very good health status" and less report "not good at all health status" compared to members of the other 3 groups (not the Haredi group). This is true for men and women. A remarkable finding relates to the Haredi group. While this group possesses low objective labor market indicators, it exhibits the highest levels of satisfaction with the economic status, labor-income and the health status.

As an illustration, Figure 7 displays the percentages of individuals who are 'very satisfied' with their economic status, within the five groups, in 2008 and 2002, for men and women separately. The most striking figure is the high satisfaction level of Haredi individuals (in particular men) and also Israeli-Arab women, although these two groups have the lowest objective economic status. These figures reassure that life satisfaction and well-being are only marginally related to income and to other objective economic determinants. Culture, perceptions and attitudes are most probably more important factors behind satisfaction. At the other end, disabled individuals and new immigrants report low levels of satisfaction with their economic status, probably, due to unfulfilled expectations. 
Figure 7: Percentages of individuals who are 'very satisfied' with their economic status, 2008 and 2002

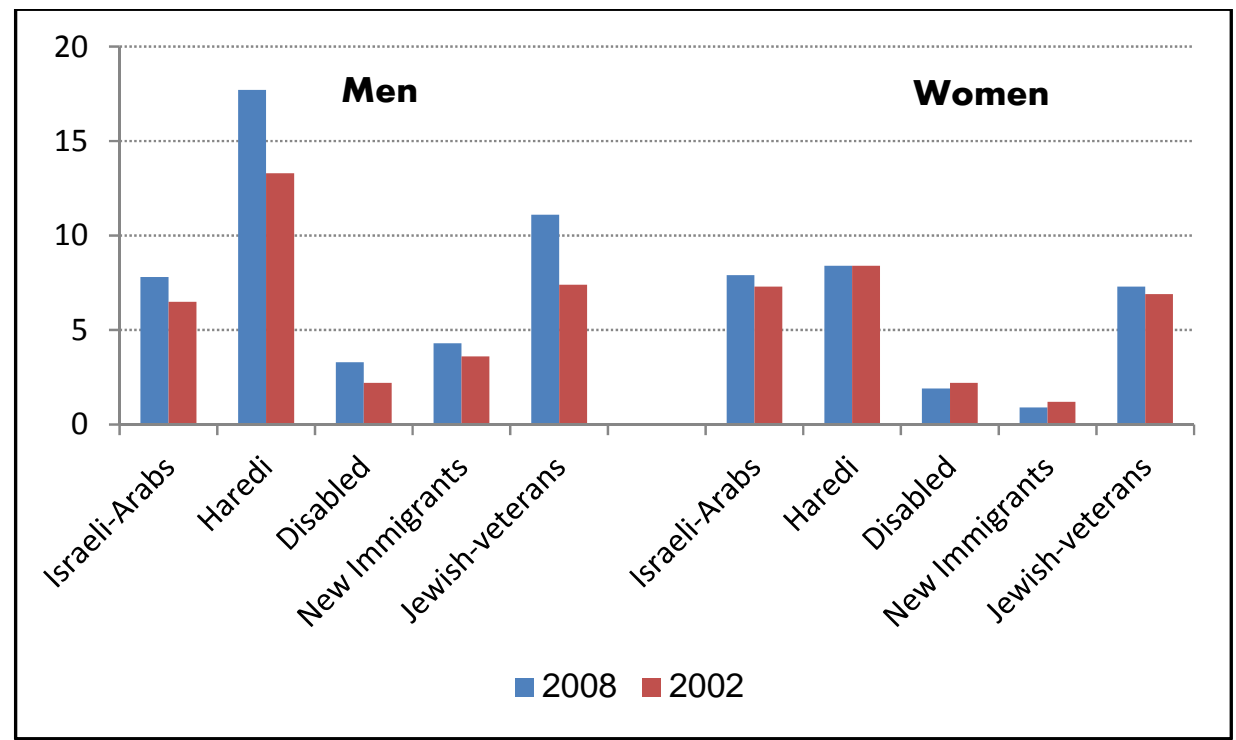

Sources: Tables 7 and 8

\section{Institutional reforms and interventions: Regulation and enforcement}

Labor regulation and enforcement in the Israeli labor market:

Employment relations in Israel (in general) are regulated by a number of legal bodies and formulas: Constitutional rights, as determined by the Basic Laws ${ }^{35}$ (Basic Law: Human Dignity and Freedom; and Basic Law: Freedom of Occupation); Statutory rights, as set out in statutes and regulations; rights set by collective agreements and extension orders of collective agreements (backed by the "Collective Agreement Law - 1957"; and the "Settlement of Labor Disputes Law - 1957”); and individual labor contracts. These legal sources are interpreted by the National Labor Court, which is the main judicial body developing labor and social security law. International standards, especially ILO conventions adopted by Israel, and also EU standards, are used by the government and the courts as guidelines (Adler and Avgar, 2003).

In Israel, there is no single authority that is responsible for the enforcement of labor legislation and collective agreements. Instead, the regulation and enforcement authority is divided among different units and institutions. The enforcement of basic labor standards is under the auspices of four institutions:

- The Ministry of Industry, Trade and Labor ('moital') that is the one which signs and activates extension orders, and is responsible for regulation and enforcement of labor law, including workers’ rights, through its various Departments: Regulation and Enforcement

\footnotetext{
${ }^{35}$ For a variety of political and ideological reasons, the first Knesset - the Israeli Parliament - decided that the written constitution will be passed chapter by chapter. So far, the Knesset has enacted eleven Basic Laws, which compose the current partial Constitution.
} 
Administration; Ombudsman for the Complaints of Foreign Workers on Workers' Rights; Equal Opportunities Employment Commission; and Labor Inspection Service for Enforcing Safety and Hygiene at the Work Place. The Regulation and Enforcement Administration is composed of two divisions: (a) the regulating division that is responsible for the administrative aspects of enforcement, including licensing (e.g., licenses of labor-contractors); and (b) the enforcement division, which conducts criminal investigations of labor law violations. This is done by: investigation of complaints submitted to the Administration, on-site inspections at workplaces, and raising awareness among groups in need of protection. ${ }^{36}$ Israel has not invested sufficiently in enforcement capacity and the Labor Inspectorate is under-funded and under-staffed ${ }^{37}$;

- The General Histadrut, although the largest trade-union, plays a limited role in the enforcement of collective agreements that it created and signed, including recent agreements in the sectors of security, and cleaning that employ a major share of contracted-workers. Moreover, as was outlined above, the Histadrut lost its institutional power as a strong trade-union, and consequently workers are encountering serious difficulties in securing their rights;

- The legislature: Most efforts to conclude standards of regulation and enforcement of labor law that relates to disadvantaged workers were initiated by the legislature. The 1996 "Law of Employment by Labor-Contractors" established licensing requirements for laborcontractors. In order to obtain a license, the applicant needs to prove that he has a clean personal legal record, a registered business, and reasonable physical premises for the business. He also has to deposit with 'moital' a bank guarantee, or other suitable guarantee of payment of wages. ${ }^{38}$ These restrictions increased the economic cost of starting a labor-contracting business and led to a decrease of about 30 percent in the number of labor-contracting firms (from a peak of 380 firms in 1998) (Nadiv, 2005). However, the decrease in the number of contracting-firms did not lead to a parallel decrease in the number of contracted-workers. Various creative arrangements are used by firms who were denied a license, to circumvent the problem, in particular, sub-contracting and illegal employment that is not reported to the tax authorities and violates basic rights of workers. Ironically, the hard regulatory provisions of the 1996 Law led to an increase,

\footnotetext{
36 As an illustration: During the time period of 2007-2010, the enforcement division carried out over 6,000 inspections, imposed over 5,000 administrative fines totaling 53 million shekel (10.6 million euro; 1 euro=about 5 shekel), submitted about 1,000 criminal indictments and sent out to employers over 1,000 warning letters (Ministry of Industry, Trade and Labor - 'moital' -, 2011)

37 There is some minor improvement: while between 2002 and 2007 only 20 inspectors were responsible for about 2.5 million employees, as of 2009 it includes 45 inspectors and 55 part-time students, dealing with 2.8 million employees. However, comparative figures for OECD countries on the number of workers per one labor inspector, demonstrate that Israel ranks at the high-end with a figure of 61.7 thousand, only after Mexico (192 thousand) and the United-States (65 thousand). Israel is way above the ILO benchmarks that are 10.0 for developed countries and 20.0 for transition economies (OECD, 2010).

${ }^{38}$ Foreign-workers are subject to somewhat different regulations: the law prohibits the licensing of a labor-contractor who provides services of foreign-workers, unless the Minister of the Interior grants special permission, upon satisfying several conditions (sec. 10). Work permits for migrant-workers are also issued by the Ministry of the Interior. The 1991 "Migrant Workers Law" refers to fines (maximum of 104,400 shekel, about 21,000 euro), as well as to the option of imprisonment (up to six months), for violations of regulations of the Law. 'Moital' attempts to enforce the 1991 Law and its regulations. For instance, in 2007, there were 693 criminal indictments filed, 48 judgments were completed, and a total of 11,169,280 shekel (about 2,250,000 euro) in fines has been collected from employers of foreign workers ('moital', 2011).
} 
rather than a decrease in the number of workers in triangular employment, who were now hired through sub-contracting arrangements (interview with Head of the Enforcement Division - Makover, February 2012). Moreover, the 1996 Law of "Employment by Labor-Contractors" created a legal framework for this type of work. Labor-contracting was facilitated and legitimized by the state (that is also a major user of contracted-labor);

- Labor courts: workers can turn to the labor court if labor laws and agreements are violated and not enforced. The labor courts include regional courts and one national court located in Jerusalem. Labor courts' jurisdiction is very broad and includes matters of: individual disputes between workers and employers, protective labor laws, collective disputes, disputes between unions and their members or an employer and his association, pension and other social-security matters (about 30 percent of cases filed), equal opportunities at the work-place, employment of contracted-workers, migrant-workers' employment and protection, strikes. The triangular relationship can also be confined by the labor courts that will look into the realities of the employment arrangement to see if the employee is integrated into the user's workplace, and based on that identify the employer. It is now clear that the Court will not accept long-term employment through intermediaries. In such cases the user will be considered the legal employer. ${ }^{39}$

\section{Employment rights of disadvantaged workers - denial and protection:}

Israeli labor-law grants all employees (whether unionized or not) wages and basic rights that provide minimal, however respectful, work and life conditions (mandatory rights, such as minimum wage, sick pay, travel allowances, annual vacation pay, maternity leave, incremental pay for overtime and for work during the official rest days). These rights are guaranteed by protective labor-law ${ }^{40}$, extension orders, and state-wide collective agreements. Additional rights are under collective agreements (fringe benefits, such as contributions of the employer to a pension fund and a training fund, reimbursement of telephone costs).

\footnotetext{
${ }^{39}$ Legislative steps in this direction have been taken already in the early-1990s: In the 1994 Kefar Ruth decision, the National Labor Court placed heavy emphasis on the objective circumstances as a guide for ascertaining the employer's identity, and clearly presumed that the user and not the contractor is the employer. Judge Porat said: "It is natural to presume that the employee and the user of his services are the real parties placed on each side of the employment contract" (Hassan El-Aharina’at v. Kefar Ruth, National Labor Court, 1994, in Davidov, 2005). Another often cited law-suit was filed in by Ilana Levinger, who was a secretary at the Ministry of Employment and Welfare (currently, the Ministry of Industry, Trade and Labor - 'moital'). She was employed for twenty years as a contractedworker, and worked there side-by-side with other employees who were employees of the State. When she was fired after 20 years of service, she applied for an injunction against her dismissal. The judges were furious when they learnt about her extreme case of "pay-rolling" and the Court ruled that Levinger should be considered a State employee, thus enjoying job security, and ordered her reinstatement (Ilana Levinger v. State of Israel, National Labor Court, 2000, in Davidov, 2005). More recent examples relate to workers at the Knesset's restaurant and to court typists.

${ }^{40}$ The following are examples of Protective Labor Laws (that also used ILO conventions and Western standards as guidelines): The Hours of Work and Rest Law (1951); The Annual Leave Law (1951); Apprenticeship Law (1953); Protection of Youth Labor Law (1953); Employment of Women Law (1954); Wage Protection Law (1958); The Labor Inspection (Organization) Law (1954); The Severance Pay Law (1963); Male and Female Workers (Equal Pay) Law (1964); The Labor Courts Law (1969); The Sick Pay Law (1976); The Minimum Wage Law (1987); Single Parent Family Law (1992); The Prevention of Sexual Harassment Law (1998); Equal Rights for Persons with Disabilities Law (1998) (Adler and Avgar, 2003).
} 
However, the processes described above exposed workers in secondary-labor sectors to the denial of their basic rights. Two examples follow:

i. A significant share of disadvantaged workers in the secondary sector do not receive the minimum wage. Gottlieb (2002) used records for the year 2000 of the Enforcement Division in the Ministry of Labor and Welfare (the previous title of the Ministry of Industry, Trade and Labor) to indicate that the probability of being paid below the minimal wage is about 10 percent for Jewish male workers, and increases dramatically when it comes to foreign-workers (probability of 80 percent), Israeli-Arab women (41 percent) and Jewish women (43 percent);

ii. Contracted-workers are often denied not only the voluntary fringe benefits, but also the mandatory benefits that are determined by labor law: a survey conducted by the Manpower Planning Authority presents evidence that 40 percent of the sampled individuals did not get 'sick pay' and 'annual vacation pay' and 20 percent did not get 'travel allowances'. Only few workers received the voluntary fringe benefits (Verzberger, 2002).

The legislature stepped in order to protect workers' rights.

- The 1996 Law of "Employment by Labor-Contractors" was meant to protect contractedlabor workers from exploitation, in particular: (i) protection of the contracted-worker's employment rights against discriminatory treatment (including the payment of fees to the contractor); (ii) in the case of long-term employment, application of the work place collective agreement to the contracted-worker, or alternatively, application of a separate collective agreement with the contractor (Article 13). This legislative restriction is aimed to prevent the use of contracted-workers as permanent replacements for in-house employees. However, the option of two different collective agreements within the same work place legitimized the inferior status of the contracted-workers. Some improvement in work conditions of contracted-labor employees have been achieved when collective agreements have been concluded with labor-contractors, in particular social security rights, such as pension; sick pay; and training/welfare fund. However, many contractors signed collective agreements that were actually less favorable for the workers (in particular in terms of job security, e.g., deprivation from the right of 'good reason' for dismissals and the right of 'severance pay' if the worker resigns; see Raday, 1999);

- More significant improvement in the rights of the contracted-worker were achieved in 2000 by an important amendment to the 1996 law. The major changes were: (i) Article 12A states that employment by a labor-contractor is limited to the duration of nine month, with an option of extension to 15 months, upon special approval of the Minister of 'moital'; and (ii) after this time-period the worker will automatically enjoy all benefits and collective agreements that apply to the user's in-house employees. Expectedly, there was an outcry of employers against the 2000 amendment. Back-of-the-envelope calculations presented by the Chamber of Commerce stated that labor costs would increase by 6 percent in the private sector and by 25-30 percent in the public sector (that is a major employer of contracted-labor), leading to an estimated dismissal of 15,000 employees, in the public sector only. ${ }^{41}$ Reservations of the employers and of other interest

\footnotetext{
${ }^{41}$ Enforcement efforts and costs were also estimated to increase by about 5 million shekel, mainly for additional
} inspection and enforcement personnel (Schwartz, 2008) 
groups, which were negatively affected by the 2000 amendment, led to successive postponements of ratification; it finally came into effect only on January $1^{\text {st }}, 2008$. The Histadrut reported that the amendment led to an immediate change in status (from contracted-workers to in-house workers) of about 15,000 employees, already in 2001 (e.g., 2,700 employees at the Clalit HMO, 2,500 at the Bezeq Telephone Company, 2,300 in government ministries; see Verzberger, 2002). However, at the same time, in order to circumvent Article 12A, labor-contractors changed their legal employer status and became 'sub-contractors' or 'suppliers of services' who are not subject to the $12 \mathrm{~A}$ amendment. By 2008, when the law came into effect, only 41.8 thousand employees remained contracted-workers, and the figure further dropped to 32.2 thousand in 2009. In parallel, the numbers of employees of sub-contractors/service-suppliers rose to 114.4 thousand in 2008 and 119.1 thousand in 2009 (see Figure 2);

- An amendment to the 1987 "Minimum Wage Law", enacted in 1998, was meant to tighten enforcement of the right for minimum wage, by placing direct responsibility on the user to pay the minimum wage, if the contractor fails to do so; ${ }^{42}$

- The Law of "Enforcement of Labor Law" (preceded by 'package deal' agreements between the General Histadrut and FIEO; Neuman, 2012), approved by the Knesset on 12.12.2011, and enacted in June 2012, relates specifically to contracted-workers. It states that both the contractor and the user of the service, will be fined and also face criminal charges if the worker will get less than the minimum hourly wage, as well as additional fringe benefits and rights (including employer contributions for dismissals and pension; annual vacation pay; sick pay; clothing; travel allowances). In parallel, 'moital' issued detailed calculations of the minimal hourly wage, with the inclusion of fringe benefits. ${ }^{43}$

○ The rights of the foreign-workers, who compose a distinctive group in the secondary labor market, are protected by the 1991 "Foreign-Workers Law". It specifies restrictions on the employment of foreign-workers as well as the workers' rights. A foreign-worker is entitled to the same working conditions as an Israeli employee. In addition, employers must give workers a written employment contract and provide private health insurance ${ }^{44}$ and proper accommodation. Special reference relates to the collection of illegal

\footnotetext{
42 Another indirect sanction against contractors violating the "Minimum Wage Law" was presented in the 2002 amendment of the Law. It prohibited public sector employers from contracting with contractors who have been convicted of violating the Minimum wage Law, unless a year has passed since the conviction (or three years in the case of multiple convictions). However, at the same time, at the initiative of the Ministry of Finance, the prohibition was relaxed, now allowing public employers to contract with firms with multiple convictions, as long as one year has passed since the last conviction; as well as introducing a series of exceptions in which the prohibition does not apply (Davidov, 2005).

43 This mandatory extended minimal wage will cover at the first stage contracted-workers of the cleaning and security services and then it will be applied to all other contracted-workers. The exact minimal hourly wage was calculated and presented by 'moital' in August 2012: The hourly wage of 31.8 shekel (about 6.4 euro) is composed of the Israeli minimal hourly wage that is (in August 2012) 22.04 shekel (and was updated in the October 2012, up to 23.12 shekel=4.6 euro), plus 9.76 shekel for the various fringe benefits. At tenders of labor-contracted cleaning services the contractors will be obliged to quote this minimal hourly wage of 31.8 shekel (and add to it 5-10 percent of profit and administrative costs) (Calcalist Business Newspaper, 15.8.2012).

${ }^{44}$ Foreign-workers are not covered by the National Health-Insurance Law, which provides all Israelis with a broad set of free health-care services. Therefore employers of foreign-workers are legally obliged to provide them with private health-insurance. Many employers of migrant-workers violate the law, by refusing to pay for their medical insurance. In the cases of need of medical treatment these individuals face major problems of paying their medical bills. Even if they are privately insured, they have to struggle with the insurance companies that try to cut costs by denying or decreasing reimbursement (Nathan, 2009).
} 
recruitment fees. ${ }^{45}$ Female foreign-workers who are giving birth are insured by The Israeli National Insurance Institute (NII) that covers costs and benefits granted by the Israeli law (costs of the delivery and of hospitalization at maternity-wards, and benefits such as maternity leave). The NII also insures foreign-workers in case of work injuries and reimburses foreign-workers whose salaries are not paid by the employer. The 1991 Law was followed by a series of regulations and guidelines. ${ }^{46}$ An amendment of the 1991 Law, in 2010, established the function of an Ombudsperson for the Complaints of Foreign Workers. It is under the auspices of 'moital' with the mandate of safeguarding the rights of foreign-workers employed in Israel; ${ }^{47}$

- The General Histadrut tried to seize her historical function as protector of workers. Following a general strike in February 2012, an agreement was signed between the General Histadrut and the Ministry of Finance, declaring that contacted-workers in the public sector who work "shoulder to shoulder" with in-house workers (whether employed by labor-contractors or by sub-contractors/suppliers-of-services) will become in-house workers after 9 months of employment. The same will apply to core-workers in the private sector. As of March 2013, this path-breaking agreement has not been implemented;

- Non-union modes of representation and civil non-labor associations (such as human rights and workers' advocacy groups) emerged and took action. These non-profit organizations voice the interests of the growing segment of disadvantaged workers, in particular, immigrants, Israeli-Arab workers and foreign-workers.

\footnotetext{
${ }^{45}$ The maximal permitted fee is 3,050 shekel (610 euro). Charging more than this maximum is criminal and can result in a fine of up to 200,000 shekel (40,000 euro) and a 6-month imprisonment. Several reports published on the recruitment process show that foreign-workers are subject to exploitation by private recruitment agencies mainly abroad. Private recruitment agencies abroad charge high and illegal fees, ranging from an average of 5,000 USD, paid by domestic care-givers from the Philippines, up to 25,000 USD from Chinese construction workers. There are no precise figures on the amount transferred to recruitment agencies in Israel. Estimates relate to 70 percent (Kemp, 2010). Bilateral agreements on recruitment could reduce rent-taking by intermediary agencies. Indeed, in July 2005, the government introduced a new recruitment method, which will include bilateral agreements with sending countries and the use of services of the International Organization for Migration (IOM). In August 2008 the new recruitment method has been approved by the Government (Kemp, 2010). However, bilateral agreements have been signed in only in 2012, and only with Thailand (21,168 foreign-workers) and Bulgaria (1,139 foreign-workers). As of January 2013, negotiations are held with five other countries (The Philippines, Nepal, Sri-Lanka, Romania and Vietnam). There are no negotiations with the Chinese government (TheMarker Economic Newspaper, 2013).

${ }^{46}$ New regulations that came into force in January 2009 relate to migrant home-care workers. These in-house migrant-workers (most of them from the Philippines, totaling, in 2010, about 57,000 workers - of which 48,000 were employed by frail older persons; See Nathan, 2009) are especially vulnerable. The 2009 regulations include supervision by a social worker who will conduct home visits and watch closely the relationship between the caregiver and the care-recipient. Figures provided an Israeli advocacy voluntary organization that is trying to protect migrant-workers against exploitation and abuse (“Kav-La'Oved” - Workers Hotline), has reported in 2010 that about 35 percent of home-care workers were subject to some kind of abuse. It should however also be added that there are cases where care-givers are abusing the old/disabled individuals that they were taking care of. Several cases have been brought to court and care-givers have been sentenced to various periods in prison.

${ }^{47}$ The Ombudsperson serves a central coordinating function in reviewing complaints and deciding if they refer to violations of regulatory laws or crimes of slavery, forced-labor or labor-trafficking. If positive - the complaints are referred to the proper authorities.
} 


\section{Policy recommendations}

\section{Round-table forums and consensus agreements:}

The old corporatist system secured autonomous space for the social partners (trade-unions and employers' associations) to self-regulate the labor market through broad collective-bargaining agreements that covered whole sectors and even the entire market. The new pluralist system resulted in the deterioration of work conditions (via triangular arrangements) of large pools of disadvantaged workers (in particular contracted-workers and migrant-workers) and exacerbated labor market segmentation and polarization. While it is unrealistic to call for the dismantling of the new forms of contracts, partial remedy could be achieved by consensus agreements to protect 'fragile' workers. There are already steps in this direction. Two examples are: (i) the collective agreement concluded by the General Histadrut and the Employers' Federation (FIEO) in 2007 on a mandatory pension scheme. The agreement was extended in 2008 by the Minister of Industry, Trade and Labor to all employers and employees in the state. It guarantees a relatively lean pension to those who have no pension coverage; (ii) a second example relates to a coalition agreement between the ruling Likud Party and the Labor Party (24/3/2009). It was agreed to establish a 'round table forum' in which representatives of the executive branch will convene with the heads of the General Histadrut (still the largest trade-union) and of the Employers' Federation (FIEO) to discuss and consult on economic issues. This tripartite partnership, which also benefitted from strong personal ties between the leaders of the General Histadrut and the FIEO, met several times and reached agreements (e.g., on: 'convalescence benefits'; protection against dismissals; sub-contracting). Mundlak (2009) relates to this 'round-table forum' as one of the "new appearances of corporatism in a pluralist environment" (page 770). In the same direction, the OECD (2010) suggests to extend the forum and invite to the bargaining table also trade-unions outside the General Histadrut, non-governmental organizations, and organizations representing smaller enterprises, so that the interests of all workers and employers will be better reflected in industrial-relations’ negotiations.

In a similar vein, at the firm-level, Raday (1999) argues that managerial flexibility (that necessitates the use of contracted-labor) is not the only way to cope with difficult social and economic realities. She proposes a different setting using techniques for consensus planning in which the employee, the manager and the union will all have a say.

On the other hand, there is also objection to round-table forums, arguing that they lead to lengthy discussions and complex decision making, thereby delaying policy making (e.g., Report of The Committee for the Examination of Employment Policy, 'moital', 2010a). We still believe that on fundamental issues, where there is a conflict of interest between the parties - consensus between the partners leads to more satisfactory and balanced agreements.

Upgrading the skills and work options of Haredi individuals and Israeli-Arab women and menActive Labor Policies (ALPS):

Active labor-market policies should be designed to help low-skilled Israelis, in particular IsraeliArab women and Haredi individuals, get into work. Greater investment in human capital, such as education and training, will help the currently non-employed to get better jobs and wages. Workers who will upgrade their skills will also have higher prospects of moving from the secondary- to the primary labor market. There is already evidence that Active Labor Policies 
(ALPs) are efficient in promoting employment within sectors of minority population groups. Investment in ALPs is relatively low in Israel, composing 0.36 of GDP and 0.89 of the Government's budget (3,093 million shekel, in 2011; with a growth-rate of 27 percent between 2005 and 2011). About one-third of it is used to subsidize childcare facilities, about one-quarter for vocational training, and only 14 percent for schemes boosting employment of the nonemployed (Bank of Israel, Annual Report 2011, Statistical Appendix Table 5-11). There are 350 unemployed individuals per each counselor in the public employment service, and less than 1 percent of the unemployed participate in vocational training (OECD, 2010). First steps to upgrade work options were taken by the "welfare to workfare" program (known as "lights for employment"), which needs to be reformed and extended nationwide. The upgrade of skills is vital for Haredi individuals and for Israeli-Arab women. There has been some effort in this direction, with special schemes designed for Haredi persons and Israeli-Arabs. Haredi women, who used to train and work as teachers, are now offered by 'moital' training in diverse fields such as: practical engineering, interior design, accounting, and computer science. They join these training tracks in growing numbers and follow-up studies by 'moital' show high rates of satisfaction and integration into the labor market (Goldfarb, 2011). Haredi men too are joining in growing numbers educational systems that are labor-market oriented. For instance, the number of Haredi men attending vocational training courses rose from about 2,000 at mid-2000s to about 6,000 in 2010. Enrollment in academic institutions rose from few hundred to about 2,500 (in 2010; see Bank Israel Annual Report, 2011). The figures are still low, but the direction is clear and so are the policy implications: proper incentives and subsides could result in major increases in employment and wages of the Haredi sector. Regarding Israeli-Arabs, an increase in the participation of Israeli-Arab women in the workforce has been a declared goal of the Israeli government for several years. Recently, the government defined fresh objectives: in the year 2020 the rate of employment of Arab women should increase to 41 percent (decision 4193 of January 2012; see Adiv, 2012). The LFPRs of Israeli-Arab women are rising mildly but the participation rate is however still very low (27.5 percent in the age group of 18-64, compared to 77.2 in the parallel Jewish age group, 'moital', 2012a). Arab women will join the labor market in growing numbers if education will rise, coupled with improved childcare and transportation facilities. Devoting larger budgets to these policies should therefore be given high priority. Measures in this direction have already been taken, but in the context of needs they are drops in the ocean. ${ }^{48}$

The role of the government: Employment equality and better enforcement of labor law and regulations:

Israel has not invested sufficiently in enforcement capacity. New enforcement modes require more enforcers and more resources that are still very scarce. This has severe effects particularly on low-paid disadvantaged workers. A recent report of the Committee for the Examination of an Employment Policy ('moital', 2010a) recommends the appointment of a senior administrator at 'moital' to be responsible for all aspects of labor-law and labor-regulations enforcement; tighten enforcement; and develop "decent work indices" (in line with the ILO guidelines), that will be used to improve enforcement. The indices will relate to: wage and employment by gender and

\footnotetext{
${ }^{48}$ For instance: Nine million shekel were invested in training 50 Arab women per year in nursing; 1000 women participated in 2011 in courses aimed at the encouragement of women to establish their own small businesses; investments were made to improve transportation in Arab localities and to establish childcare centers (Adiv, 2012).
} 
occupation; women in managerial positions (compared with men); full-timers who do not receive the minimum wage; and child labor.

Adiv (2012) provides a suggestion to improve the employability of Israeli-Arab women and men by absorbing large numbers of Arab women and men into the public sector via the administration of affirmative action policies. The public sector (in Israel and elsewhere) was found to be more open and generally operate according to principles of equality. Because government agencies do not seek to maximize profit, they can pursue a policy of equal pay to all workers. Blank (1985), for example, has pointed out that the state appears to be more effective in enforcing universal guidelines concerning the employment of disadvantaged groups (e.g., ethnic minorities and women) and in adopting affirmative action policies. Although the Israeli government has not established a formal affirmative action policy with respect to ethnic groups and other minorities, there is evidence that the public sector does serve as a "sheltered labor market" for Arab male and female employees, and for Jewish women as well (Lewin-Epstein and Semyonov, 1994). LewinEpstein and Semyonov (1994) also show that the public sector actually favors Arab employees who receive higher returns to education compared to Jewish public-sector workers, and also compared to their companions in the private sector. Women are already highly-represented in the public sector. A recent report of 'moital' (2012a) shows that in 2010, 60.2 percent of Israeli-Arab working women and 46.3 percent of working Jewish women, were employed in the public sector (mainly in education, health-care and public administration). The government can, however, do more, by increasing and enforcing the job quotas for minority groups in the public sector. According to Government Decision 2579 from November 2007, by the year 2012, the percentage of Israeli-Arabs working in the public sector should have reached 10 percent. The percentage of Israeli-Arabs employed in the public sector increased from 7 percent in 2009 to 7.8 percent in 2011, but is still below the goal of 10 percent (which was a modest goal, since the percentage of working-age Arabs in the Israeli population is 17.8) (Adiv, 2012).

As noted above, low-skilled (Israeli and Palestinian) workers are constantly substituted by growing numbers of overseas foreign-workers (see Table 5), mainly in the agriculture, construction and care-giving industries. As a result, tens of thousands of Palestinian construction workers, who were employed in Israel in the past, today suffer unemployment and poverty. Or, many Israeli-Arab farm workers have been dismissed, or are employed on a part-time or temporary basis during periods of an overload of work, due to intensified employment of foreignworkers from Thailand (Adiv, 2012). Despite a clear economic and political assertion that employing Israeli-Arab and Palestinian workers should be preferred over employment of migrant-workers from foreign countries such as Thailand (agriculture), the Philippines, Nepal and India (nursing and care-work) and China (construction), little has been done to cease the import of foreign-labor. The government has adopted a series of recommendations to reduce the number of overseas migrant-workers, but they have not been implemented.

A different strategy for reducing the number of migrant-workers is voiced by economists who suggest imposing a sufficiently high tax on employing a foreign-worker, so that hiring Israeli workers will become considerably cheaper. The decline in profitability of employing foreignworkers would likely lead to a decrease in demand and as a result, those foreign-workers who fail to find a job would leave the country (e.g., Ben-David, 2010).

As a major employer of contracted-workers, the Israeli government should also take the lead by stamping out discriminatory practices and by securing the rights of the large share of contracted- 
workers employed in the public sector. The government should also favor private employers who protect the rights of their employees in tender processes, thereby encouraging fair employment. 


\section{References}

Achdut, L., Sola, V. and Eizenbach, Z. (1998), Employment by Labor-Only Contractors, New Histadrut General Federation of Employees, Economics and Social Research Institute, Friederich Ebert Foundation.

Adiv, A. (2012), Arab Women: The Israeli Government Report in Response to OECD's 16 Recommendations on Welfare and Labor Contains Much Talk but Little Willingness for Action. The Workers Advice Center (WAC/Ma'an). Published online on 29.9.2012. Downloadable at: http://www.wac-maan.org.il/en/print/article_253

Adler S.J. and Avgar A. (2003), National Labour Law Profile: The State of Israel, ILO Report. Geneva: Social Dialogue, Labour Law and Labour Administration Department.

Amos, O. and Baharav, T. (2012), "The Unionization of Cleaning Workers at Ben-Gurion University of the Negev as a Test Case for Coping with Multi-Dimensional Institutional Oppression". In: Mishori, D. and Maor, A. (eds), Precarious Employment: Systematic Exclusion and Exploitation in the Labor Market. The Social Economic Academy and Ahva Publishing: 113-127 (in Hebrew).

Association for Civil Rights in Israel, periodical online publications, figures can be found at www.acri.org.il.

Bank of Israel, Annual Report, various issues (in Hebrew).

Bartman, D. (1998), "Foreign Workers in Israel: History and Theory”, International Migration Review 32(2): 303-325.

Ben-David, D. (2010), Israel's Labor market: Today, in the Past and in Comparison with the West. Jerusalem: The Taub Center for Social Studies in Israel, Policy Paper Series, No. 2010.05.

Ben-Israel, R. (1999), “Outsourcing: Employment of Workers by Manpower Contractors, a Different Interpretation Converting Formal to Authentic Employment”, Labor Law Yearbook, a publication of the Israeli Society for Labor Law and Social Security (in Hebrew).

Ben-Moshe, E. (2012), Changes in the Structure and Composition of the Israeli Population in the Coming Twenty Years, by Cultural/Religious Segment, and its Implications for the Labor Force. Jerusalem: Ministry of Industry, Trade and Labor - Administration of Planning, Research and Economics (in Hebrew).

Blanchflower, D. and Freeman, R. (1992), "Unionism in the United States and Other Advanced OECD Countries”, Industrial Relations 31(1): 56-79.

Blank, R. (1985), “An Analysis of Workers' Choice between Employment in the Public and Private Sectors”, Industrial and Labor Relations Review 38: 211-224.

Calcalist (Israeli Business Newspaper), (15/8/2012), The Ministry of Industry, Trade and Labor will Determine the Minimum Hourly Wage of Contracted Cleaning Workers. Report (in Hebrew).

Cain, G.G. (1976), "The Challenge of the Segmented Labor Market Theories to Orthodox Theory: A Survey”, Journal of Economic Literature 14(4): 1215-1257. 
Card, D, Lemieux, T. and Riddel, W.C. (2004), “Unions and Wage Inequality”, Journal of Labor Research 25(4): 557-562.

Cohen, Y., Haberfeld, Y., Mundlak, G. and Saporta, I. (2003), "Unpacking Union Density: Membership and Coverage in the Transformation of the Israeli IR System", Industrial Relations 42(4): 692-711.

Cohen, Y., Haberfeld, Y., Kristal, T. and Mundlak, G. (2007), “The State of Organized Labor in Israel“, Journal of Labor Research 28(2): 255-273.

Corcoran, M.E. (1979), "Work Experience, Labor Force Withdrawals and Women's Wages: Empirical Results using the 1976 Panel of Income Dynamics". In: Llyd C.B., Andrews, E.S., and Gilroy, C.L. (eds.), Women in the Labor Market. New York: Columbia University Press.

Danziger, L. and Neuman, S. (2005), "Delays in Renewal of Labor Contracts: Theory and Evidence”, Journal of Labor Economics 23(2): 341-371.

Davidi, E. (2012), "A Brief History of Precarious Employment in Israel". In: Mishori, D. and Maor, A. (eds), Precarious Employment: Systematic Exclusion and Exploitation in the Labor Market. The Social Economic Academy and Ahva Publishing: 39-44 (in Hebrew).

Davidov, G. (2005), “Enforcement Problems in 'Informal' Labor Markets: A View from Israel”, Comparative Labor, Law and Policy Journal 27(3): 3-25.

Eckstein, Z. (2008), A Report by the Inter-Ministerial Committee for the Formulation of Labor Migration Policy. Jerusalem: State of Israel (in Hebrew).

Endeweld, M. and Galia, A. (2013), Work Histories of Workers in Israel, 2005-2010. Jerusalem: The National Insurance Institute (in Hebrew).

Fenssirer, U. (2011), Employment of Immigrants and Contracted-Workers. Jerusalem: The Knesset Research and Information Center. Downloadable at: www.knesset.gov.il(in Hebrew).

Flug, K., Kasir (Kaliner) N. and Ofer, G. (1992), The Absorption of Soviet Immigrants into the Labor Market from 1990 onwards: Aspects of Occupational Substitution and Retention, Discussion paper No. 92.13. Jerusalem: Bank of Israel, Research Department.

Freeman, R.B. (1980), "Unionism and the Dispersion of Wages”, Industrial and Labor Relations Review 34 (October): 3-23.

Galnoor, Y. (2007), Public Administration in Israel: Development, Structure, Functions and Reforms. Jerusalem: The Hebrew University, Akademon Publications (in Hebrew).

Galnoor, Y., Rosenbloom, D. and Yaroni, A. (1999), "Reform of the Public Administration Sector”. In: Nachmias, D. and Menahem, G. (eds.), Public Policy in Israel, pp. 117-158. Jerusalem: The Israel Democracy Institute (in Hebrew).

Galin, A. (1999), “Outsourcing: The Organizational and Managerial Aspect”, Labor Law Yearbook, a publication of the Israeli Society for Labor Law and Social Security (in Hebrew). 
Goldfarb, Y. (2011), Alternative Training Modes in Girls' Schools of the Haredi Population: The 'Chen' program. The Ministry of Industry, Trade and Labor ('moital') - Administration of Planning, Research and Economics (in Hebrew).

Gottlieb, D. (2002), The Effect of Non-Israeli Migrant Workers on Employment, Wages and Inequality: 1995-2000, Discussion Paper. Jerusalem: Bank of Israel, Research Department (in Hebrew).

Haberfeld, Y. (1995), "Why do Workers Join Unions? The Case of Israel”, Industrial and Labor Relations Review 48(4): 656-670.

Haberfled, I, Cohen, Y., Mundlak, G. and Saporta, I. (2006), "Industrial Density in Israel Between 2000-2006: A Period of Stagnation”, Mimeo (in Hebrew).

Harpaz, I. (2006), "The State of Trade Unionism in Israel". In: Phelan, C. (ed.), Trade Union Revitalisation: Trends and Prospects in 34 Countries. Oxford: Peter Lang, pp. 445-460.

Harpaz, I. (2012), "Adverse Employment and Negative Work Environment in Israel". In: Mishori, D. and Maor, A. (eds), Precarious Employment: Systematic Exclusion and Exploitation in the Labor Market. The Social Economic Academy and Ahva Publishing: 31-38 (in Hebrew).

Hodson, R. and Kaufman, R.L. (1981), "Circularity in the Dual Economy: Comment on Tolbert, Horan and Beck”, American Journal of Sociology 86: 881-887.

Hodson, R. and Kaufman, R.L. (1982), “Economic Dualism: A Critical Review”, American Sociological Review 47: 727-739.

International Labor Organization (ILO) (1997), Contract Labor, Report VI(1). Geneva: 85 ${ }^{\text {th }}$ Session of the International Labor Conference.

International Labor Organization (ILO) (2002), Report of the Committee on the Informal Economy .Geneva: $90^{\text {th }}$ Session of the International Labor Conference.

International Monetary Fund (IMF), (2011), World Economic outlook.

Israel, Central Bureau of Statistics (CBS) (2002, 2008), Social Surveys, Module: Pensions and Retirement Savings (2002), and Module: Social Mobility (2008).

Israel, Central Bureau of Statistics (CBS) (2011), Main Science and Technology Indicators.

Israel, Central Bureau of Statistics (CBS) (2012), Labor Force Survey.

Israel, Central Bureau of Statistics (CBS), Annual Social Survey, various issues.

Israel, Central Bureau of Statistics (CBS), Annual Statistical Abstract, various issues.

Israel, National Insurance Institute (NII), Annual Report, various issues (in Hebrew).

Israel, National Insurance Institute (NII), Annual Poverty Report, various issues (in Hebrew).

Johnson, G. (1975), "Economic Analysis of Trade Unionism”, American Economic Review 65(June): 23-28. 
Kalleberg, A.L. (2000), "Nonstandard Employment Relations: Part-time, Temporary and Contract Work”, Annual Review of Sociology 26: 341-365.

Kemp, A. (2010), Reforming Policies on Foreign Workers in Israel. OCED: Social, Employment and Migration Working Papers, No. 103.

Kristal, T. (2002), "Decentralization and Collective Wage Agreements in Israel: 1957-1998”, Labor, Society and Law 9: 17-42 (in Hebrew).

Kristal, T. and Cohen, Y. (2007), "Decentralization of Collective Wage Agreements and Rising Inequality in Israel”, Industrial Relations 46(3): 613-635.

Kristal, T., Cohen, Y. and Mundlak, G. (2011), "Fringe Benefits and Income Inequality", Research in Social Stratification and Mobility 29: 351-369.

Lewin-Epstein, N. and Semyonov, M. (1994), "Sheltered Labor Market, Public Sector Employment, and Socioeconomic Returns to Education of Arabs in Israel”, The American Journal of Sociology 100(3): 622-651.

Makover, R. (2012), Head of the Enforcement Division at the Ministry of Industry, Trade and Labor. Personal interview.

Maman, D. (1999), “’”The Social Organization of the Israeli Economy: A Comparative Analysis”, Israel Affairs 5(2-3): 87-102.

McNabb, R and Psacharopoulos, G. (1981), "Further Evidence for the Relevance of the Dual Labor Market Hypothesis for the UK”, Journal of Human Resources 16: 442-458.

Michelson, N. (2012), The Effects of Personal Contracts in Public Administration in Israel, on Length of Service, Discussion paper No. 2012.02. Jerusalem: Bank of Israel, Research Department (in Hebrew).

Ministry of Finance (2006, 2009, 2012), Report on Wage Costs in the Public Sector and in Government Ministries. Jerusalem: Administration of Wages and Labor Agreements (in Hebrew). Downloadable at: http://hsgs.mof.gov.il/Documents/2012-3.pdf (report of 2011).

Ministry of Industry, Trade and Labor - 'moital' (2010a), Report of The Committee for the Examination of Employment Policy (in Hebrew).

Ministry of Industry, Trade and Labor - 'moital' (2010b), Populations of: Israeli Arabs, Haredi Workers, Disabled Workers, and Immigrants - Characteristics of Employment, Health and Satisfaction: Data of the 2002 and 2008 Social Surveys (in Hebrew).

Ministry of Industry, Trade and Labor -'moital' (2011), Response to the Questionnaire on: 'The Effectiveness of Labor Law and the Role of Labor Inspectorate, distributed by the International Society for Labor and Social Security Law.

Ministry of Industry, Trade and Labor -'moital' (2012a), The Israeli-Arab Working Woman. A report issued (on 2/9/2012) for the international 'woman day' (in Hebrew). 
Ministry of Industry, Trade and Labor - 'moital' (2012b), Special Survey on Fair Employment and Enforcement of Labor Law (in Hebrew).

Mundlak, G. (2004), Industrial Relations in the Era of Transition. Jerusalem: Israeli Democracy Institute (in Hebrew).

Mundlak, G. (2009), “Addressing the Legitimacy Gap in the Israeli Corporatist Revival”, British Journal of Industrial Relations 47(4): 765-787.

Nadiv, R. (2005), Licensed Labor-Contractors in Israel, Jerusalem: Ministry of Industry, Trade and Labor - Administration of Planning, Research and Economics (in Hebrew).

Nathan, G. (2009), Foreign Workers in Israel: An Overview and Assessment of Major Problems. Jerusalem: The Knesset Research and Information Center. Downloadable at: www.knesset.gov.il (in Hebrew).

Nathan, G. (2011), Non-Israelis in Israel: 2010-2011. Jerusalem: The Knesset Research and Information Center. Downloadable at: www.knesset.gov.il (in Hebrew).

Neuman, S. (2005), “Aliya to Israel: Immigration under Conditions of Adversity". In: Zimmerman, K. (ed), European Migration, What Do We Know? Oxford: Oxford University Press.

Neuman, Shlomo (2012). Former Director General of the Israeli Federation of Employers (FIEO): 1970-2012. Personal interview.

Neuman, S. and Ziderman, A. (1986), “Testing the Dual Labor Market Hypothesis: Evidence from the Israel Labor Mobility Survey”, The Journal of Human Resources 21(2): 230-237.

Neuman, S. and Ziderman, A. (1992), "Benefits of Women's Education within Marriage: Results for Israel in a Dual Labor Context”, Economic Development and Cultural Change 40(2): 413424.

Neuman, S. and Ziderman, A. (2003), Work Histories of Israeli Men and Women, 1983-1995. Discussion paper No. 6-2003. Tel-Aviv University: The Pinhas Sapir Center for Development.

OECD, (2010), OECD Reviews of Labour Markets and Social Policies: Israel.

OECD, (2011), Economic Outlook.

Paz-Fuchs, A. (2010), Workers in the Era of Privatization. Jerusalem: The Van Leer Institute (in Hebrew).

Piore, M.J. (1969), “On-the-Job Training in a Dual Labor Market”. In: Weber, A.R. et al. (eds.), Public-Private Manpower Policies. Madison, Wisconsin: Industrial Relations Research Association.

Piore, M.J. (1971), “The Dual Labor Market Theory and Implications”. In: Gordon, D. (ed.), Problems in Political Economy: An Urban Perspective. Lexington, MA: Heath. 
Raab, M., Ruland, M., Schonberger, B., Blossfeld, H.P., Hofacker, D., Buchholz, S. and Schmelzer, P. (2008), "Global Index - A Sociological Approach to Globalization Measurement“, International Sociology 23(4): 596-631.

Rabin-Margalioth, S. (2011), "Regulating Individual Employment Contracts Through Good Faith Duties", Comparative Labor Law and Policy Journal 32: 663-683.

Raday, F. (1999), “The Insider-Outsider Position of Labor-only Contracting”, Comparative Labor, Law and Policy Journal 20(3): 413-445.

Ramos, J. and Ballell, P, (2009), "Globalization, New Technologies and Dual Labor Markets: The Case of Europe", Journal of Information, Communication and Ethics in Society 74(4): 258279.

Rifkin, J. (1995), The End of Work. New York: Putnam Book.

Schwartz, E. (2008), Amendment to the law of Contracted Labor - Cost Analysis. Jerusalem: The Knesset Research and Information Center. Downloadable at: www.knesset.gov.il (in Hebrew).

Stewart, M.B. and Greenhalgh, C.A. (1984), "Work History Patterns and the Occupational Attainment of Women", Economic Journal 94 (September).

Sussman, Z. (1995), "From Collective Agreements to Personal Contracts: Wages, Labor Relations and the Histadrut”, The Economic Quarterly 42(1): 17-35 (in Hebrew).

Sussman, Z. and Zakai, D. (1996), The Decentralization of Collective Bargaining and Changes in the Compensation Structure in Israel's Public Sector, Discussion paper No. 96.04. Jerusalem: Bank of Israel, Research Department.

Sussman, Z. and Zakai, D. (2004), Wage Gaps in the Public Service in Israel in the 1990s, Discussion paper No. 04.02. Jerusalem: Bank of Israel, Research Department (in Hebrew).

Swirski, I. (2009), "Not the Law Alone, Not the Histadrut Alone: Advancing Workers' Organization as an Efficient Tool for Self Enforcement of Rights and for Personal Empowering", Legal Performance: A periodical for Law and Social Justice 2: 87-104 (in Hebrew).

TheMarker (Economic Newspaper) (7.1.2013), "The Importation of Chinese Construction Workers will be Discontinued - to avoid Human Trafficking" (in Hebrew).

Tolbert, C.M., Horan, P.M. and Beck E.M. (1980), “The Structure of Economic Sectoration: A Dual Economy Approach”, American Journal of Sociology 85: 1095-1116.

Tyree, A. (1981), Occupational Socio-Economic Status, Ethnicity and Sex in Israel: Considerations in Scale Construction”, Megamot, September (in Hebrew).

United Nations (2011), Human Development Report 2011 - Sustainability and Equity: A Better Future for All.

Verzberger, R. (2002), Employment by Labor-Contracting Firms. Jerusalem: The Knesset Research and Information Center. Downloadable at: www.knesset.gov.il(in Hebrew). 
Virtanen, M., Kivimaki, M., Joensuu, M., Virtanen, P. and Elovainio M. (2005), “Temporary Employment and Health: A Review”, International Journal of Epidemiology 34: 610-622.

Visser, J. (2006), “Union Membership Statistics in 24 countries”, Monthly Labor Review, January: 38-49.

Vosko, L.F. (1997), "Legitimizing the Triangular Employment Relationship: Emerging International labor Standards from a Comparative Perspective" Comparative Labor Law and Policy Journal 19(1): 43-54.

Vosko, L.F. (2006), "Precarious Employment: Towards an Improved Understanding of Labor Market Insecurity". In: Vosko, L.F. (ed.): Precarious Employment: Understanding Labor Market Insecurity in Canada. McGill-Queen's University Press: 3-39.

Wallach, S. (2008), “Temporary? Agency Workers in Israel”, The International Journal of Comparative Labor Law and Industrial Relations 24(3): 423-444.

World Bank, World Development Indicators, various years.

World Bank, World Bank Statistics, various years.

Zilony, E. (2001), “The Legal Revolution of Employment by Labor-Contractors”, Human Resources, November (in Hebrew).

Zilony, E. (2012), Head of the Economic and Social Department, in the General Histadrut. Personal interview. 
Table 1: Descriptive statistics for the Israeli economy (1990-2011)

\begin{tabular}{ccccccc}
\hline \hline Year & $\begin{array}{c}\text { Growth of } \\
\text { per-capita } \\
\text { GDP }\end{array}$ & $\begin{array}{c}\text { Gini Index of } \\
\text { net (gross) } \\
\text { income }\end{array}$ & $\begin{array}{c}\text { Infl. } \\
\text { Rate (\%) }\end{array}$ & $\begin{array}{c}\text { Unemp } \\
\text { rate } \\
\text { (\%) }\end{array}$ & $\begin{array}{c}\text { Number of } \\
\text { immig. }\end{array}$ & $\begin{array}{c}\text { Unemp. rate } \\
\text { among } \\
\text { immigrants (\%) }\end{array}$ \\
\hline \hline $\mathbf{1 9 9 0}$ & $6.3(3.0)$ & $0.326(0.480)$ & 17.6 & 9.6 & 199,516 & \\
$\mathbf{1 9 9 1}$ & $5.7(-0.5)$ & $0.327(0.490)$ & 18.0 & 10.6 & 176,100 & 38.9 \\
$\mathbf{1 9 9 2}$ & $6.8(5.1)$ & $0.339(0.498)$ & 9.4 & 11.2 & 77,057 & 28.7 \\
$\mathbf{1 9 9 3}$ & $3.8(1.1)$ & $0.329(0.494)$ & 11.2 & 10.0 & 76,805 & 19.4 \\
$\mathbf{1 9 9 4}$ & $7.0(4.4)$ & $0.344(0.502)$ & 14.5 & 7.8 & 79,844 & 13.3 \\
$\mathbf{1 9 9 5}$ & $6.6(3.9)$ & $0.336(0.497)$ & 8.1 & 6.8 & 76,361 & 9.6 \\
$\mathbf{1 9 9 6}$ & $5.5(2.8)$ & $0.328(0.496)$ & 10.6 & 6.6 & 70,919 & 9.2 \\
$\mathbf{1 9 9 7}$ & $3.4(0.8)$ & $0.333(0.504)$ & 7.0 & 7.5 & 66,221 & 10.0 \\
$\mathbf{1 9 9 8}$ & $4.1(1.6)$ & $0.347(0.507)$ & 8.6 & 8.6 & 56,730 & 11.7 \\
$\mathbf{1 9 9 9}$ & $3.4(0.7)$ & $0.355(0.512)$ & 1.3 & 8.9 & 76,766 & 11.3 \\
$\mathbf{2 0 0 0}$ & $9.3(6.4)$ & $0.350(0.509)$ & 0.0 & 8.8 & 60,201 & 10.4 \\
$\mathbf{2 0 0 1}$ & $-0.2(-2.6)$ & $0.357(0.528)$ & 1.4 & 9.3 & 43,473 & 10.6 \\
$\mathbf{2 0 0 2}$ & $-0.6(-2.6)$ & $0.368(0.537)$ & 6.5 & 10.3 & 33,570 & 11.8 \\
$\mathbf{2 0 0 3}$ & $1.5(-0.3)$ & $0.368(0.526)$ & -1.9 & 10.7 & 23,273 & 11.2 \\
$\mathbf{2 0 0 4}$ & $4.8(3.0)$ & $0.380(0.532)$ & 1.2 & 10.4 & 20,899 & 10.4 \\
$\mathbf{2 0 0 5}$ & $4.9(3.1)$ & $0.388(0.522)$ & 2.4 & 9.0 & 21,183 & 8.5 \\
$\mathbf{2 0 0 6}$ & $5.6(3.7)$ & $0.392(0.524)$ & -0.1 & 8.4 & 19,269 & 7.2 \\
$\mathbf{2 0 0 7}$ & $5.5(3.6)$ & $0.383(0.513)$ & 3.4 & 7.3 & 18,131 & 6.3 \\
$\mathbf{2 0 0 8}$ & $4.0(2.2)$ & $0.385(0.512)$ & 3.8 & 6.1 & 13,701 & 5.4 \\
$\mathbf{2 0 0 9}$ & $0.8(-0.9)$ & $0.389(0.510)$ & 3.9 & 7.5 & 14,574 & 7.1 \\
$\mathbf{2 0 1 0}$ & $4.8(2.9)$ & $0.384(0.504)$ & 2.7 & 6.7 & 16,633 & 5.6 \\
$\mathbf{2 0 1 1}$ & $4.7(2.8)$ & $0.379(0.497)$ & 2.2 & 5.6 & 16,892 & 5.5 \\
$\mathbf{O E C D}$ & $1.9(1.4)$ & $0.31(0.45)$ & 2.9 & 8.0 & & \\
\hline \hline
\end{tabular}

Sources: Israel, Central Bureau of Statistics, Annual Statistical Abstract, various issues; Bank of Israel, Annual Report, various issues; National Insurance Institute, Annual Report, various issues; National Insurance Institute, Annual Poverty Report, various issues

Notes: The Gini Index was calculated (by the National Insurance Institute) employing the Israeli equivalence scale that is marginally different from the equivalence scale used by OECD countries. Employing the OECD scale to the Israeli data results in somewhat lower indices. For instance: using the OECD scale for 2005 leads to indices of 0.374 (net) and 0.504 (gross) (see, Bank of Israel, Annual Report for 2010, chapter eight, Table 8-5, page 277) compared to respective figures of 0.388 and 0.522 with the Israeli scale. Differences are similar for other years too. The OECD Gini figures are for the mid-2000s. Other OECD figures are for 2011 
Table 2: Descriptive statistics of the Israeli labor market (1990-2011)

\begin{tabular}{|c|c|c|c|c|c|c|}
\hline Year & $\begin{array}{c}\text { Labor Force } \\
\text { Participation } \\
\text { Rate (LFPR) } \\
(\%) \\
\end{array}$ & $\begin{array}{c}\text { Percent } \\
\text { part-time } \\
\text { (out of } \\
\text { employed) } \\
\end{array}$ & $\begin{array}{c}\text { Immig. } \\
\text { (arrived } \\
\text { after 1989) } \\
\text { LFPR } \\
\end{array}$ & $\begin{array}{c}\text { Foreign- } \\
\text { workers in } \\
\text { business } \\
\text { sector (\%) } \\
\end{array}$ & $\begin{array}{c}\text { Work- } \\
\text { days lost } \\
\text { due to } \\
\text { strikes } \\
\end{array}$ & $\begin{array}{c}\text { Real monthly } \\
\text { income } \\
\text { (Israelis,index, } \\
\text { 2004=100) } \\
\end{array}$ \\
\hline 1990 & 51.5 & 26.5 & & 9.0 & "1,071,279 & "88.35 \\
\hline 1991 & 51.7 & 25.1 & 44.9 & 8.2 & 97,923 & 86.75 \\
\hline 1992 & 52.0 & 24.6 & 52.0 & 9.8 & 386,658 & 87.86 \\
\hline 1993 & 52.8 & 24.8 & 54.0 & 8.0 & $1,636,866$ & 87.60 \\
\hline 1994 & 53.6 & 24.6 & 54.9 & 8.0 & 792,533 & 89.35 \\
\hline 1995 & 54.0 & 24.8 & 53.1 & 9.7 & 257,796 & 91.04 \\
\hline 1996 & 53.6 & 24.1 & 53.5 & 11.9 & 189,792 & 92.33 \\
\hline 1997 & 53.4 & 24.0 & 54.0 & 13.8 & $2,416,254$ & 94.70 \\
\hline 1998 & 53.4 & 24.7 & 54.1 & 16.1 & $1,438,944$ & 96.76 \\
\hline 1999 & 53.8 & 24.2 & 55.3 & 16.6 & $1,640,891$ & 99.12 \\
\hline 2000 & 54.3 & 23.6 & 56.6 & 16.1 & $2,011,263$ & 105.07 \\
\hline 2001 & 54.3 & 24.9 & 56.7 & 15.5 & $2,039,974$ & 107.65 \\
\hline 2002 & 54.1 & 23.8 & 56.8 & 15.2 & $1,488,120$ & 100.95 \\
\hline 2003 & 54.5 & 24.7 & 57.2 & 13.8 & $2,725,159$ & 97.80 \\
\hline 2004 & 55.0 & 26.3 & 58.1 & 12.1 & $1,224,423$ & 100.00 \\
\hline 2005 & 55.2 & 26.8 & 58.2 & 11.5 & 244,236 & 101.13 \\
\hline 2006 & 55.6 & 26.7 & 59.5 & 11.1 & 136,189 & 102.45 \\
\hline 2007 & 56.3 & 27.1 & 60.4 & 11.4 & $2,548,627$ & 104.24 \\
\hline 2008 & 56.5 & 26.8 & 61.1 & 12.0 & 87,151 & 103.90 \\
\hline 2009 & 57.0 & 26.3 & 62.8 & 12.3 & 208,691 & 101.26 \\
\hline 2010 & 57.4 & 26.8 & 63.1 & 11.7 & 168,864 & 102.01 \\
\hline 2011 & 57.4 & & 64.0 & 11.9 & & 102.43 \\
\hline
\end{tabular}

Sources: Israel, Central Bureau of Statistics, Annual Statistical Abstract, various issues; Bank of Israel, Annual Report, various issues

Notes: Foreign-workers include legal and illegal foreign-workers, and Palestinian workers (figures of illegal workers are estimates) 
Table 3: Violations of workers' rights, by type of employment status (percent), 2012

\begin{tabular}{|c|c|c|}
\hline & $\begin{array}{l}\text { contracted- } \\
\text { workers } \\
\end{array}$ & $\begin{array}{l}\text { in-house } \\
\text { workers }\end{array}$ \\
\hline $\begin{array}{l}\text { (i) Denial of overtime payments, or payments lower than the } \\
\text { official rates }\end{array}$ & 54.5 & 16.4 \\
\hline $\begin{array}{l}\text { (ii) Denial of holiday payments, or payments lower than the } \\
\text { official rates }\end{array}$ & 27.3 & 22.4 \\
\hline (iii) Worker does not have an official written contract & 56.7 & 39.0 \\
\hline $\begin{array}{l}\text { (iv) Late payment of monthly income - on the 10th of the month or } \\
\text { later }\end{array}$ & 53.6 & 44.9 \\
\hline $\begin{array}{l}\text { (v) The worker did not get the agreed-upon monthly salary, at least } \\
\text { once during the last year }\end{array}$ & 13.3 & 5.5 \\
\hline
\end{tabular}

Source: Ministry of Industry, Trade and Labor ('moital'), special Survey on "Fair Employment and Enforcement of Labor Law", 2012b 
Table 4: Average duration (months) of spells of employment (in-spells) and nonemployment (out-spells), 1983-1995 and 2005-2010. NII Administrative data

\begin{tabular}{|c|c|c|c|c|c|c|c|c|}
\hline \multirow[t]{2}{*}{ Work history } & \multicolumn{2}{|c|}{$\begin{array}{c}\text { Men } \\
\text { 1983-1995 } \\
\text { (146 months) } \\
\end{array}$} & \multicolumn{2}{|c|}{$\begin{array}{c}\text { Women } \\
1983-1995 \\
\text { (146 months) } \\
\end{array}$} & \multicolumn{2}{|c|}{$\begin{array}{c}\text { Men } \\
\text { 2005-2010 } \\
\text { (72 months) } \\
\end{array}$} & \multicolumn{2}{|c|}{$\begin{array}{c}\text { Women } \\
\text { 2005-2010 } \\
\text { (72 months) } \\
\end{array}$} \\
\hline & $\begin{array}{c}\text { Absolute } \\
\text { duration, } \\
\text { months } \\
\end{array}$ & $\begin{array}{l}\text { Relative } \\
\text { duration }\end{array}$ & $\begin{array}{c}\text { Absolute } \\
\text { duration, } \\
\text { months } \\
\end{array}$ & $\begin{array}{l}\text { Relative } \\
\text { duration }\end{array}$ & $\begin{array}{c}\text { Absolute } \\
\text { duration, } \\
\text { months } \\
\end{array}$ & $\begin{array}{l}\text { Relative } \\
\text { duration }\end{array}$ & $\begin{array}{c}\text { Absolute } \\
\text { duration, } \\
\text { months } \\
\end{array}$ & $\begin{array}{l}\text { Relative } \\
\text { duration }\end{array}$ \\
\hline \multicolumn{9}{|l|}{ One spell } \\
\hline $\begin{array}{l}\text { in-spell (current) - } \\
\text { month }\end{array}$ & 146 & 1.00 & 146 & 1.00 & 72 & 1.00 & 72 & 1.00 \\
\hline \multicolumn{9}{|l|}{ Two spells } \\
\hline out-spell - months & 35.0 & 0.35 & 51.1 & 0.35 & 30.5 & 0.42 & 32.3 & 0.45 \\
\hline $\begin{array}{l}\text { in-spell (current) - } \\
\text { month }\end{array}$ & 111.0 & 0.65 & 94.9 & 0.65 & 41.5 & 0.58 & 39.7 & 0.55 \\
\hline \multicolumn{9}{|l|}{ Three spells } \\
\hline in-spell - month & 42.3 & 0.30 & 43.8 & 0.30 & 30.6 & 0.43 & 30.9 & 0.43 \\
\hline out-spell - month & 11.7 & 0.08 & 11.7 & 0.08 & 8.0 & 0.11 & 7.5 & 0.10 \\
\hline $\begin{array}{l}\text { in-spell (current) - } \\
\text { month }\end{array}$ & 92.0 & 0.62 & 90.5 & 0.62 & 33.4 & 0.46 & 33.6 & 0.47 \\
\hline \multicolumn{9}{|l|}{ Four spells } \\
\hline out-spell - month & 21.9 & 0.25 & 36.5 & 0.25 & 19.1 & 0.27 & 20.3 & 0.28 \\
\hline In-spell - month & 29.2 & 0.18 & 26.3 & 0.18 & 16.5 & 0.23 & 16.5 & 0.23 \\
\hline "out-spell - month & 13.1 & 0.12 & 17.5 & 0.12 & 9.0 & 0.13 & 9.2 & 0.13 \\
\hline $\begin{array}{l}\text { in-spell (current) - } \\
\text { month }\end{array}$ & 81.8 & 0.45 & 65.7 & 0.45 & 27.4 & 0.38 & 26.0 & 0.36 \\
\hline \multicolumn{9}{|l|}{ Five spells } \\
\hline in-spell - month & 36.5 & 0.22 & 32.1 & 0.22 & 20.9 & 0.29 & 20.4 & 0.28 \\
\hline out-spell - month & 10.2 & 0.07 & 10.2 & 0.07 & 6.2 & 0.09 & 5.6 & 0.08 \\
\hline "in-spell - month & 33.6 & 0.22 & 32.1 & 0.22 & 14.7 & 0.20 & 16.9 & 0.23 \\
\hline out-spell - month & 8.8 & 0.07 & 10.2 & 0.07 & 6.3 & 0.09 & 6.2 & 0.09 \\
\hline $\begin{array}{l}\text { in-spell (current) - } \\
\text { month }\end{array}$ & 56.9 & 0.42 & 61.3 & 0.42 & 24.0 & 0.33 & 23.0 & 0.32 \\
\hline $\begin{array}{l}\text { Six spells or more } \\
\text { percentage of } \\
\text { workers }\end{array}$ & 23.6 percent & & $\begin{array}{c}40.3 \\
\text { percent }\end{array}$ & & $\begin{array}{c}15.2 \\
\text { percent }\end{array}$ & & $\begin{array}{c}19.1 \\
\text { percent }\end{array}$ & \\
\hline
\end{tabular}

Sources: Calculations based on Neuman and Ziderman (2003, Table 3) and on Endeweld and Galia (2013) 
Table 5: Israeli and (non-Israeli) foreign-workers: Non-Palestinian foreign-workers and Palestinian workers (thousands) (1990-2011)

\begin{tabular}{|c|c|c|c|c|c|c|}
\hline Year & $\begin{array}{c}\text { (1) } \\
\text { Non- } \\
\text { Palestinian } \\
\text { foreign- } \\
\text { workers }\end{array}$ & $\begin{array}{c}(2) \\
\text { Palestinian } \\
\text { workers }\end{array}$ & $\begin{array}{c}(3)=(1)+(2) \\
\text { Total } \\
\text { foreign- } \\
\text { workers } \\
\text { (non-Israeli) }\end{array}$ & $\begin{array}{c}(4)=(1) /(3) \\
\text { Share of } \\
\text { non- } \\
\text { Palestinian } \\
\text { foreign- } \\
\text { workers } \\
(\%) \\
\end{array}$ & $\begin{array}{c}\text { (5) } \\
\text { Total Israeli } \\
\text { Employed }\end{array}$ & $\begin{array}{c}6=(3) /(5) \\
\text { Share of } \\
\text { foreign- } \\
\text { workers }(\%)\end{array}$ \\
\hline 1990 & 2.5 & 107.7 & 110.2 & 2.3 & $1,491.6$ & 7.4 \\
\hline 1991 & 9.0 & 97.8 & 106.8 & 8.4 & $1,583.3$ & 6.7 \\
\hline 1992 & 16.6 & 115.6 & 132.2 & 12.6 & $1,650.0$ & 8.0 \\
\hline 1993 & 29.6 & 84.0 & 113.6 & 26.1 & $1,751.2$ & 6.5 \\
\hline 1994 & 51.6 & 70.0 & 121.6 & 42.4 & $1,871.1$ & 6.5 \\
\hline 1995 & 92.5 & 60.1 & 152.6 & 60.6 & $1,968.1$ & 7.8 \\
\hline 1996 & 137.4 & 58.3 & 195.7 & 70.2 & $2,013.4$ & 9.7 \\
\hline 1997 & 159.1 & 74.7 & 233.8 & 68.0 & $2,040.8$ & 11.5 \\
\hline 1998 & 173.7 & 106.0 & 279.7 & 62.1 & $2,072.4$ & 13.5 \\
\hline 1999 & 184.6 & 113.6 & 298.2 & 61.9 & 2,136.6 & 14.0 \\
\hline 2000 & 206.0 & 96.0 & 301.9 & 68.2 & $2,221.2$ & 13.6 \\
\hline 2001 & 246.3 & 47.8 & 294.1 & 83.7 & $2,270.4$ & 13.0 \\
\hline 2002 & 254.5 & 30.3 & 284.8 & 89.4 & $2,284.4$ & 12.5 \\
\hline 2003 & 220.6 & 38.8 & 259.4 & 85.0 & $2,330.2$ & 11.1 \\
\hline 2004 & 195.8 & 37.4 & 233.2 & 84.0 & $2,400.8$ & 9.7 \\
\hline 2005 & 182.7 & 46.3 & 229.0 & 79.8 & $2,493.7$ & 9.2 \\
\hline 2006 & 180.3 & 48.9 & 229.2 & 78.7 & $2,573.6$ & 8.9 \\
\hline 2007 & 193.2 & 53.1 & 246.3 & 78.4 & $2,682.0$ & 9.2 \\
\hline 2008 & 211.3 & 58.9 & 270.2 & 78.2 & $2,776.7$ & 9.7 \\
\hline 2009 & 220.2 & 55.7 & 275.9 & 79.8 & $2,785.9$ & 9.9 \\
\hline 2010 & 215.2 & 60.6 & 275.8 & 78.0 & $2,938.3$ & 9.4 \\
\hline 2011 & 222.0 & 65.9 & 287.9 & 77.1 & $3,024.7$ & 9.5 \\
\hline
\end{tabular}

Sources: Israel, Central Bureau of Statistics, Annual Statistical Abstract, various issues; Bank of Israel, Annual Report and Statistical Tables, various issues; author's calculations

Notes: Figures include legal (with work permits), as well as illegal foreign-workers. The latter are estimates provided by the Central Bureau of Statistics. The sum of foreign-workers and Palestinian workers does not always add up to the total number of non-Israeli workers, due to rounding 
Table 6: Average characteristics of workers of the primary- and secondary-sector

\begin{tabular}{lcc}
\hline \hline & Primary sector & Secondary sector \\
\hline \hline Gross full-time monthly income & $10,677.87$ & $5,962.22$ \\
(shekel) & 16.48 & 13.18 \\
Schooling (years) & 41.77 & 40.11 \\
Age (years) & 9.62 & 7.65 \\
Tenure at work-place (year) & \\
\hline \hline
\end{tabular}

Sources: Calculations based on data from the 2005-2011 CBS annual Social Surveys

Note: Primary and secondary sectors were defined by occupation 
Table 7: Characteristics/satisfaction of disadvantaged groups (Israeli-Arabs, Haredi, disabled, new-immigrants) vs. Jewish-veterans - Men, 2008 and 2002 (in parentheses)

\begin{tabular}{|c|c|c|c|c|c|}
\hline & $\begin{array}{l}\text { Israeli- } \\
\text { Arabs }\end{array}$ & Haredi & disabled & Immig. & $\begin{array}{l}\text { Jewish- } \\
\text { veteran }\end{array}$ \\
\hline \multicolumn{6}{|l|}{ Employment characteristics } \\
\hline Employed (\%) & $\begin{array}{c}72.6 \\
(63.9)\end{array}$ & $\begin{array}{c}40.4 \\
(33.1)\end{array}$ & $\begin{array}{c}58.7 \\
(44.7)\end{array}$ & $\begin{array}{c}75.1 \\
(64.9)\end{array}$ & $\begin{array}{c}76.8 \\
(75.9)\end{array}$ \\
\hline $\begin{array}{r}\text { Unemployed (\% - within the labor } \\
\text { force) }\end{array}$ & $\begin{array}{c}6.5 \\
(10.8)\end{array}$ & $\begin{array}{c}6.9 \\
(8.2)\end{array}$ & $\begin{array}{c}6.7 \\
(17.5)\end{array}$ & $\begin{array}{c}3.9 \\
(15.9)\end{array}$ & $\begin{array}{c}4.6 \\
(8.9)\end{array}$ \\
\hline Not in labor force (\%) & $\begin{array}{c}22.3 \\
(28.4)\end{array}$ & $\begin{array}{c}56.5 \\
(63.9)\end{array}$ & $\begin{array}{c}37.1 \\
(45.8)\end{array}$ & $\begin{array}{c}21.9 \\
(22.8)\end{array}$ & $\begin{array}{c}19.5 \\
(16.7)\end{array}$ \\
\hline $\begin{array}{r}\text { In non-professional occupations } \\
\text { (\% of employed) }\end{array}$ & $\begin{array}{l}12.6 \\
(8.9)\end{array}$ & $\begin{array}{c}5.9 \\
(0.0)\end{array}$ & $\begin{array}{c}8.6 \\
(9.9)\end{array}$ & $\begin{array}{c}14.1 \\
(11.4)\end{array}$ & $\begin{array}{c}4.4 \\
(5.7)\end{array}$ \\
\hline $\begin{array}{r}\text { Monthly income above } 10,000 \\
\text { shekel (\% of employed) }\end{array}$ & $\begin{array}{c}10.3 \\
(11.0)\end{array}$ & $\begin{array}{c}18.2 \\
(25.7)\end{array}$ & $\begin{array}{c}18.6 \\
(22.9)\end{array}$ & $\begin{array}{l}16.4 \\
(8.7)\end{array}$ & $\begin{array}{c}34.8 \\
(36.2)\end{array}$ \\
\hline \multicolumn{6}{|l|}{ Personal characteristics } \\
\hline Academic education (\%) & $\begin{array}{c}12.4 \\
(17.0)\end{array}$ & $\begin{array}{c}9.5 \\
(12.2)\end{array}$ & $\begin{array}{c}11.4 \\
(16.8)\end{array}$ & $\begin{array}{c}30.6 \\
(36.6)\end{array}$ & $\begin{array}{c}25.2 \\
(23.9)\end{array}$ \\
\hline Use a computer (\%) & $\begin{array}{c}48.2 \\
(30.1)\end{array}$ & $\begin{array}{c}45.0 \\
(32.1)\end{array}$ & $\begin{array}{c}52.6 \\
(31.8)\end{array}$ & $\begin{array}{c}76.1 \\
(48.5)\end{array}$ & $\begin{array}{c}79.4 \\
(60.2)\end{array}$ \\
\hline $\begin{array}{r}\text { Use internet (\% - out of computer } \\
\text { users) }\end{array}$ & $\begin{array}{c}83.1 \\
(54.9)\end{array}$ & $\begin{array}{c}57.0 \\
(21.0)\end{array}$ & $\begin{array}{c}89.4 \\
(63.8)\end{array}$ & $\begin{array}{c}95.5 \\
(65.7)\end{array}$ & $\begin{array}{c}94.2 \\
(75.1)\end{array}$ \\
\hline \multicolumn{6}{|l|}{ Satisfaction with economic } \\
\hline Very satisfied (\%) & $\begin{array}{c}7.8 \\
(6.5)\end{array}$ & $\begin{array}{c}17.7 \\
(13.3)\end{array}$ & $\begin{array}{c}3.3 \\
(2.2)\end{array}$ & $\begin{array}{c}4.3 \\
(3.6)\end{array}$ & $\begin{array}{l}11.1 \\
(7.4)\end{array}$ \\
\hline Not satisfied at all (\%) & $\begin{array}{c}22.7 \\
(32.0)\end{array}$ & $\begin{array}{c}8.6 \\
(11.3)\end{array}$ & $\begin{array}{c}32.5 \\
(44.2)\end{array}$ & $\begin{array}{c}21.3 \\
(27.4)\end{array}$ & $\begin{array}{c}11.2 \\
(17.6)\end{array}$ \\
\hline \multicolumn{6}{|l|}{ Satisfaction with labor income } \\
\hline (employed) $\quad$ Very satisfied (\%) & $\begin{array}{c}5.5 \\
(6.4)\end{array}$ & $\begin{array}{l}11.9 \\
(9.5)\end{array}$ & $\begin{array}{c}4.0 \\
(6.1)\end{array}$ & $\begin{array}{c}5.0 \\
(2.1)\end{array}$ & $\begin{array}{l}10.7 \\
(7.9)\end{array}$ \\
\hline Not satisfied at all (\%) & $\begin{array}{l}15.0 \\
(22.2)\end{array}$ & $\begin{array}{c}19.2 \\
(15.5)\end{array}$ & $\begin{array}{c}24.7 \\
(32.8)\end{array}$ & $\begin{array}{c}18.8 \\
(30.9)\end{array}$ & $\begin{array}{l}13.0 \\
(15.7)\end{array}$ \\
\hline \multicolumn{6}{|l|}{ Self-assessed health status } \\
\hline Very good (\%) & $\begin{array}{c}46.0 \\
(46.9)\end{array}$ & $\begin{array}{c}73.2 \\
(71.9)\end{array}$ & $\begin{array}{c}9.3 \\
(8.2)\end{array}$ & $\begin{array}{c}29.7 \\
(22.8)\end{array}$ & $\begin{array}{c}58.9 \\
(52.8)\end{array}$ \\
\hline Not good at all (\%) & $\begin{array}{c}4.6 \\
(9.8) \\
\end{array}$ & $\begin{array}{c}1.9 \\
(0.6) \\
\end{array}$ & $\begin{array}{c}15.1 \\
(21.6)\end{array}$ & $\begin{array}{c}4.9 \\
(4.1)\end{array}$ & $\begin{array}{c}1.9 \\
(2.9)\end{array}$ \\
\hline 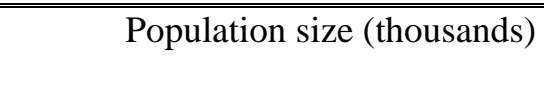 & $\begin{array}{c}337 \\
(240)\end{array}$ & $\begin{array}{l}152 \\
(89)\end{array}$ & $\begin{array}{c}297 \\
(274)\end{array}$ & $\begin{array}{l}125 \\
(98)\end{array}$ & $\begin{array}{c}1452 \\
(1309)\end{array}$ \\
\hline
\end{tabular}

Sources: Israeli Central Bureau of Statistics - Social Survey, 2002 and 2008. In: Ministry of Industry, Trade and Labor, "Populations of: Israeli Arabs, Haredi Workers, Disabled Workers, and Immigrants - Characteristics of Employment, Health and Satisfaction", 2010b

Notes: Israeli-Arabs include Moslems, Christians and Druze; Disabled workers are workers who reported a severe or a very severe health problem; The immigrants' group is composed of immigrants who arrived in the country after 1995 
Table 8: Characteristics/satisfaction of disadvantaged groups (Israeli-Arabs, Haredi, disabled, new-immigrants) vs. Jewish-veterans - Women, 2008 and 2002 (in parentheses)

Jewish-

\begin{tabular}{|c|c|c|c|c|c|}
\hline & Israeli-Arabs & Haredi & Disabled & Immig. & veteran \\
\hline \multicolumn{6}{|l|}{ Employment characteristics } \\
\hline \multirow[t]{2}{*}{ Employed (\% ) } & 24.5 & 53.9 & 44.0 & 64.3 & 69.9 \\
\hline & $(19.4)$ & $(48.0)$ & (36.9) & $(56.2)$ & $(65.7)$ \\
\hline \multirow{2}{*}{$\begin{array}{r}\text { Unemployed (\% - within the labor } \\
\text { force) }\end{array}$} & 14.2 & 7.2 & 10.7 & 7.7 & 6.9 \\
\hline & $(15.2)$ & $(12.4)$ & $(12.1)$ & $(12.5)$ & $(10.1)$ \\
\hline \multirow[t]{2}{*}{ Not in labor force (\%) } & 71.4 & 41.8 & 50.7 & 30.3 & 24.9 \\
\hline & $(77.1)$ & $(45.2)$ & $(58.0)$ & $(35.8)$ & $(26.9)$ \\
\hline \multirow{2}{*}{$\begin{array}{r}\text { In non-professional occupations (\% } \\
\text { of employed) }\end{array}$} & 14.0 & 0.0 & 15.1 & 20.2 & 4.6 \\
\hline & $(11.5)$ & $(0.0)$ & $(12.7)$ & $(26.9)$ & $(6.0)$ \\
\hline \multirow{2}{*}{$\begin{array}{r}\text { Monthly income above } 10,000 \\
\text { shekel (\% of employed) }\end{array}$} & 1.4 & 3.5 & 4.2 & 2.5 & 13.6 \\
\hline & $(0.0)$ & $(0.0)$ & $(5.0)$ & $(2.2)$ & $(11.9)$ \\
\hline \multicolumn{6}{|l|}{ Personal characteristics } \\
\hline \multirow[t]{2}{*}{ Academic education (\%) } & 10.0 & 13.1 & 14.9 & 30.6 & 30.2 \\
\hline & $(16.7)$ & $(13.6)$ & $(21.4)$ & $(31.4)$ & $(28.8)$ \\
\hline \multirow[t]{2}{*}{ Use a computer (\%) } & 37.8 & 45.4 & 45.6 & 69.8 & 76.6 \\
\hline & $(18.9)$ & $(36.5)$ & $(29.0)$ & $(37.1)$ & $(58.0)$ \\
\hline \multirow{2}{*}{$\begin{array}{r}\text { Use internet (\% - out of computer } \\
\text { users) }\end{array}$} & 75.8 & 52.5 & 91.2 & 95.0 & 94.0 \\
\hline & $(40.3)$ & $(33.6)$ & $(60.0)$ & $(66.1)$ & $(67.5)$ \\
\hline \multicolumn{6}{|l|}{ Satisfaction with economic status } \\
\hline \multirow{2}{*}{ Very satisfied (\%) } & 7.9 & 8.4 & 1.9 & 0.9 & 7.3 \\
\hline & (7.3) & $(8.4)$ & $(2.2)$ & $(1.2)$ & (6.9) \\
\hline \multirow[t]{2}{*}{ Not satisfied at all (\%) } & 21.2 & 9.8 & 34.7 & 25.4 & 15.6 \\
\hline & $(27.1)$ & $(12.9)$ & $(36.1)$ & (33.3) & $(18.3)$ \\
\hline \multicolumn{6}{|l|}{ Satisfaction with labor income } \\
\hline \multirow{2}{*}{ (employed) } & 4.7 & 2.7 & 2.5 & 1.4 & 6.4 \\
\hline & $(7.8)$ & $(5.8)$ & (3.7) & (1.3) & (7.3) \\
\hline \multirow[t]{2}{*}{ Not satisfied at all (\%) } & 12.6 & 17.0 & 34.2 & 21.6 & 19.2 \\
\hline & $(21.5)$ & $(21.9)$ & $(30.3)$ & $(25.7)$ & (19.9) \\
\hline \multicolumn{6}{|l|}{ Self-assessed health status } \\
\hline \multirow[t]{2}{*}{ Very good (\%) } & 38.3 & 63.9 & 5.9 & 23.1 & 52.0 \\
\hline & $(43.3)$ & $(62.8)$ & (7.3) & $(15.0)$ & $(49.0)$ \\
\hline \multirow[t]{2}{*}{ Not good at all (\%) } & 5.9 & 0.4 & 17.8 & 7.0 & 2.8 \\
\hline & $(6.2)$ & $(1.3)$ & $(17.9)$ & $(4.3)$ & $(2.9)$ \\
\hline \multirow[t]{2}{*}{$\begin{array}{l}\text { Population size (thousands) } \\
\end{array}$} & 337 & 126 & 384 & 156 & 1489 \\
\hline & (229) & (93) & (317) & $(117)$ & (1364) \\
\hline
\end{tabular}

Source: Israeli Central Bureau of Statistics - Social Survey, 2002 and 2008. In: Ministry of Industry, Trade and Labor, "Populations of Israeli Arabs, Haredi Workers, Disabled Workers, and Immigrants - Characteristics of Employment, Health and Satisfaction", 2010b

Notes: Israeli-Arabs include Moslems, Christians and Druze; Disabled workers are workers who reported a severe or a very severe health problem; The immigrants' group is composed of immigrants who arrived in the country after 1995 